\title{
Cerium(III) and cerium(IV) nitrate complexes of trialkylphosphine oxides
}

Coles Simon $\mathrm{J}^{1}$, Sarah J. Fieldhouse ${ }^{2}$, Wim T. Klooster ${ }^{1}$ and Andrew W. G. Platt ${ }^{2^{*}}$

1. UK National Crystallography Service, Chemistry, University of Southampton, Highfield Campus, Southampton, SO17 1BJ, UK

2. School of Law Policing and Forensic Science, Staffordshire University, Leek Road, Stoke-on-Trent, ST4 $2 D F, U K$

\section{Abstract}

The reactions of ammonium cerium(IV) nitrate, $\left(\mathrm{NH}_{4}\right)_{2} \mathrm{Ce}\left(\mathrm{NO}_{3}\right)_{6}$ (CAN) with trialkylphosphine oxides, $\mathrm{R}_{3} \mathrm{PO}$ $\left(\mathrm{R}=\mathrm{Et},{ }^{\mathrm{P}} \mathrm{Propyl},{ }^{\mathrm{n}} \mathrm{Bu}_{3},{ }^{\mathrm{B}} \mathrm{Bu} \mathrm{u}_{3} \mathrm{PO},{ }^{\mathrm{B}} \mathrm{Bu} \mathrm{u}_{3} \mathrm{PO}, \mathrm{Cy}_{3} \mathrm{PO}(\mathrm{Cy}=\mathrm{cyclohexyl})\right.$ and $\mathrm{Oct}_{3} \mathrm{PO}(\mathrm{Oct}=\mathrm{n}$-octyl)) have been investigated by 31-P NMR spectroscopy in a variety of conditions. Reactions with acetone solutions of excess of CAN and $\mathrm{R}_{3} \mathrm{PO}$ and of solid CAN with chloroform solutions of $\mathrm{R}_{3} \mathrm{PO}$ and aqueous solutions of CAN with chloroform solutions of $\mathrm{R}_{3} \mathrm{PO}$ led to the observation of $\mathrm{Ce}\left(\mathrm{NO}_{3}\right)_{4}\left(\mathrm{R}_{3} \mathrm{PO}\right)_{2}$. 31-P NMR spectroscopy and conductimetric titration of acetone solutions of CAN with $\mathrm{R}_{3} \mathrm{PO}$ confirm the initial reactions is the formation of $\mathrm{Ce}\left(\mathrm{NO}_{3}\right)_{4}\left(\mathrm{R}_{3} \mathrm{PO}\right)_{2}(\mathrm{R}=\mathrm{Et}, \mathrm{Bu}, \mathrm{Cy}$, Oct) followed by a slower reaction to form the ionic $\left[\mathrm{Ce}\left(\mathrm{NO}_{3}\right)_{3}\left(\mathrm{R}_{3} \mathrm{PO}\right)_{3}\right]\left[\mathrm{NO}_{3}\right]$. The isolation of pure cop-lexes has not proved possible in most cases but crystals suitable for $\mathrm{x}$-ray analysis were extracted in some instances. The structures of the Ce(IV) complexes $\left[\mathrm{Ce}\left(\mathrm{NO}_{3}\right)_{4}\left(\mathrm{Cy} \mathrm{C}_{3} \mathrm{PO}\right)_{2}\right]$ and $\left[\mathrm{Ce}\left(\mathrm{NO}_{3}\right)_{3}\left(\mathrm{Et} \mathrm{Pt}_{3} \mathrm{PO}\right)_{3}\right]\left[\mathrm{NO}_{3}\right]$ and the related $\mathrm{Ce}(\mathrm{III})$ complexes $\left[\mathrm{Ce}\left(\mathrm{NO}_{3}\right)_{3}\left(\mathrm{C}{ }_{3} \mathrm{PO}\right)_{3}\right]$ and $\left[\mathrm{Ce}\left(\mathrm{NO}_{3}\right)_{3}\left(\mathrm{H}_{2} \mathrm{O}\right)_{3}\left(\mathrm{Et}_{3} \mathrm{PO}\right)\right]$ are reported.

\section{Introduction}

Whilst many cerium(IV) complexes are known with a variety of ligands [1] complexes with phosphine oxides are rather rare[1,2]. Given the large number of coordination compounds between trivalent lanthanides (including cerium(III)) and phosphine oxides [2] this is surprising. The synthesis and structure of $\mathrm{Ce}\left(\mathrm{NO}_{3}\right)_{4}\left(\mathrm{Ph}_{3} \mathrm{PO}\right)_{2}$ by reaction of ceric ammonium nitrate (CAN) with triphenylphosphine oxide in acetone was reported in 1971 [3] but since then no structures of Ce(IV) nitrate with phosphine oxides have been reported. A thermally unstable complex with $\mathrm{Ph}_{2} \mathrm{P}(\mathrm{O}) \mathrm{CH}_{2} \mathrm{C}(\mathrm{O}) \mathrm{Ph}$ was isolated and characterised as $\mathrm{Ce}\left(\mathrm{NO}_{3}\right)_{3}\left(\mathrm{Ph}{ }_{2} \mathrm{P}(\mathrm{O}) \mathrm{CHC}(\mathrm{O}) \mathrm{Ph}\right)\left(\mathrm{Ph}_{2} \mathrm{P}(\mathrm{O}) \mathrm{CH}_{2} \mathrm{C}(\mathrm{O}) \mathrm{Ph}\right)_{2}$ on the basis of elemental analysis and infrared spectroscopy[4]. A cerium(IV) complex, $\mathrm{Ce}\left(\mathrm{NO}_{3}\right)_{4}\left({ }^{\mathrm{t}} \mathrm{BuPhPOC}{ }_{2} \mathrm{H}_{4} \mathrm{POPh}{ }^{t} \mathrm{Bu}\right)$ was prepared from $\mathrm{CAN}$ and the 
ligand in acetone and characterised by spectroscopy and elemental analysis but the structure was not reported [5]. The complex $\mathrm{Ce}\left(\mathrm{NO}_{3}\right)_{3}\left(\left(\mathrm{n}-\mathrm{C}_{8} \mathrm{H}_{17}\right) \mathrm{PhP}(\mathrm{O}) \mathrm{CH}_{2} \mathrm{~N}^{\mathrm{i}} \mathrm{Bu}_{2}\right)_{3}$ undergoes reversible one electron oxidation in acetonitrile solution but the Ce(IV) complex formed was not further characterised [6 ]. In view of the relative lack of studies on Ce(IV) nitrate - phosphine oxide complexes we report our study of the reactions between CAN and a variety of trialkyl phosphine oxides. In particular we hoped to establish whether the synthesis was applicable to other $\mathrm{R}_{3} \mathrm{PO}$ and if the previously reported structure for $\mathrm{Ce}\left(\mathrm{NO}_{3}\right)_{4}\left(\mathrm{Ph}_{3} \mathrm{PO}\right)_{2}$ is typical of $\mathrm{Ce}(\mathrm{IV})$ nitrate - phosphine oxide complexes.

\section{Results and discussion}

We report three types of reaction which have been carried out in an attempted to prepare Ce(IV) complexes. All the reactions use CAN as the source of Ce(IV) and differ only in the solubility of various components in the solvent systems employed. The overall reaction is indicated below

$\left(\mathrm{NH}_{4}\right)_{2} \mathrm{Ce}\left(\mathrm{NO}_{3}\right)_{6}+2 \mathrm{R}_{3} \mathrm{PO} \rightarrow \mathrm{Ce}\left(\mathrm{NO}_{3}\right)_{4}\left(\mathrm{R}_{3} \mathrm{PO}\right)_{2}+2 \mathrm{NH}_{4} \mathrm{NO}_{3}$

A solvent in which both $\mathrm{CAN}, \mathrm{R}_{3} \mathrm{PO}$ and the $\mathrm{Ce}(\mathrm{IV})$ phosphine oxide complex are soluble, and in which ammonium nitrate is not was chosen. Acetone has been previously employed for this type of reaction and we have found this and acetonitrile to be appropriate solvents.

The reaction using an aqueous / chloroform biphasic solvent system in which CAN and ammonium nitrate remain in the aqueous phase and the phosphine oxide and the $\mathrm{Ce}$ (IV) complexes remain in the organic layer offers a potentially attractive synthesis allowing for easy separation of the product.

Reactions between a chloroform solution of $\mathrm{R}_{3} \mathrm{PO}$ and solid CAN is also attractive as the $\mathrm{Ce}$ (IV) complex would be the only chloroform soluble product.

Solution NMR and conductivity study

Reactions between CAN and $\mathrm{R}_{3} \mathrm{PO}$ were studied in deuterated acetone and chloroform.

In acetone the reactions in 1:1 and 1:2 CAN: $\mathrm{R}_{3} \mathrm{PO},(\mathrm{R}=\mathrm{Et}, \mathrm{PPr}, \mathrm{Bu}, \mathrm{Oct})$, ratios gave a single sharp signal assigned to $\mathrm{Ce}\left(\mathrm{NO}_{3}\right)_{4}\left(\mathrm{R}_{3} \mathrm{PO}\right)_{2}$. With higher ratios of $\mathrm{R}_{3} \mathrm{PO}$ the sharp peak was initially superimposed on a 
broad signal $\left(\mathrm{W}_{1 / 2}\right.$ about $\left.400-500 \mathrm{~Hz}\right)$ and on standing the spectra showed only a broad signal. These observations are consistent with the formation of 1:3 complexes, possibly $\left[\mathrm{Ce}\left(\mathrm{NO}_{3}\right)_{3}\left(\mathrm{R}_{3} \mathrm{PO}\right)_{3}\right]^{+} \mathrm{NO}_{3}{ }^{-}$(see below) in dynamic equilibrium with free $\mathrm{R}_{3} \mathrm{PO}$ as indicated in Scheme 1.

\section{Scheme 1}

The reaction between $\mathrm{R}_{3} \mathrm{PO}$ and $\mathrm{CAN}$

$$
\begin{array}{ll}
\left(\mathrm{NH}_{4}\right)_{2} \mathrm{Ce}\left(\mathrm{NO}_{3}\right)_{6}+\mathrm{R}_{3} \mathrm{PO} & \stackrel{\text { Fast }}{\longrightarrow}\left[\mathrm{Ce}\left(\mathrm{NO}_{3}\right)_{4}\left(\mathrm{R}_{3} \mathrm{PO}\right)_{2}\right]+2 \mathrm{NH}_{4} \mathrm{NO}_{3} \\
{\left[\mathrm{Ce}\left(\mathrm{NO}_{3}\right)_{4}\left(\mathrm{R}_{3} \mathrm{PO}\right)_{2}\right]+\mathrm{R}_{3} \mathrm{PO} \stackrel{\text { Slow }}{\longrightarrow}\left[\mathrm{Ce}\left(\mathrm{NO}_{3}\right)_{3}\left(\mathrm{R}_{3} \mathrm{PO}\right)_{3}\right]^{+}+\mathrm{NO}_{3}^{-}}
\end{array}
$$

Variable temperature 31-P NMR studies were carried out between -40 to $50^{\circ} \mathrm{C}$ with a range of $\mathrm{R}(\mathrm{R}=\mathrm{Et}, \mathrm{Bu}$ and Oct) to confirm this. At $-40^{\circ} \mathrm{C}$ the spectra for the CAN/Et ${ }_{3} \mathrm{PO}$ system are resolved into two broad $\left(\mathrm{W}_{1 / 2}\right.$ about $500 \mathrm{~Hz}$ ) peaks at 110.0 and $71.2 \mathrm{ppm}$, which on warming to $-20^{\circ} \mathrm{C}$ coalesce into a single broad peak $\left(\mathrm{W}_{1 / 2} 1 \mathrm{kHz}\right)$ which becomes sharper with increasing temperature indicative of increasingly rapid exchange giving a resonance at $87.8 \mathrm{ppm}\left(\mathrm{W}_{1 / 2} 270 \mathrm{~Hz}\right)$ at $50^{\circ} \mathrm{C}$. The spectra for $\mathrm{R}=\mathrm{Bu}$ and Oct were similar with the exception that the separate signals for the Oct ${ }_{3} \mathrm{PO} / \mathrm{CAN}$ system were not resolved at low temperature implying faster exchange than observed for the smaller phosphine oxides. A typical set of spectra is shown for the CAN / Et ${ }_{3} \mathrm{PO}$ system in Figure 1 


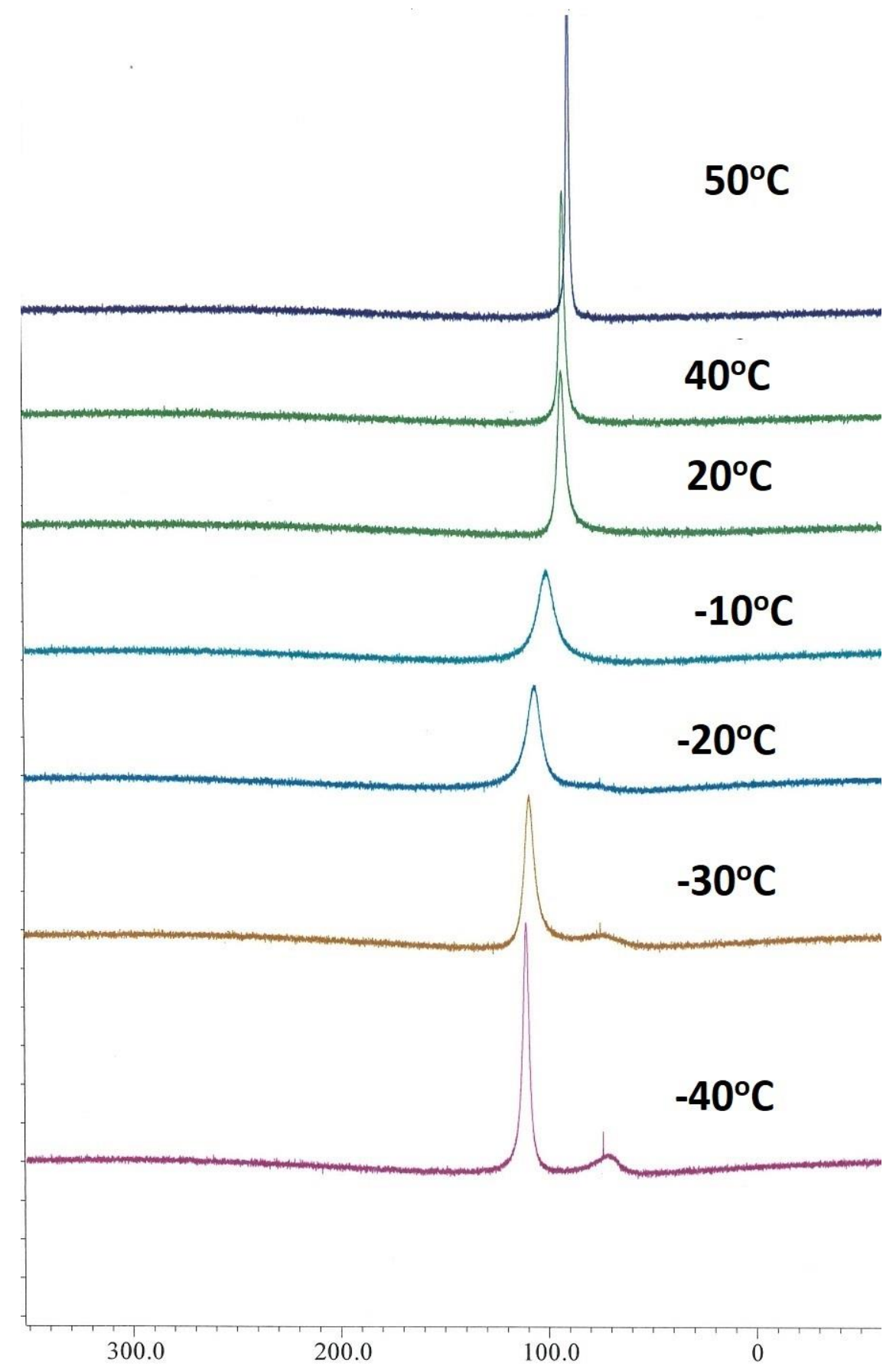

Figure 1 The variable temperature 31-P NMR spectra of the CAN / Et ${ }_{3} \mathrm{PO}$ system in $\mathrm{d}_{6}$ acetone

Further confirmation was obtained from conductivity titrations in acetone and a typical plot is shown in Figure 1. The conductivity of a solution of CAN decreased on addition of $\mathrm{R}_{3} \mathrm{PO}$ until a 2:1 ratio and remained constant thereafter, consistent with the formation of insoluble ammonium nitrate and neutral $\mathrm{Ce}\left(\mathrm{NO}_{3}\right)_{4}\left(\mathrm{R}_{3} \mathrm{PO}\right)_{2}$ complex (equation (1)). The conductivities of the 3:1 solution slowly increase on standing, consistent with displacement of nitrate ion from the coordination sphere of the metal (equation (2)). 


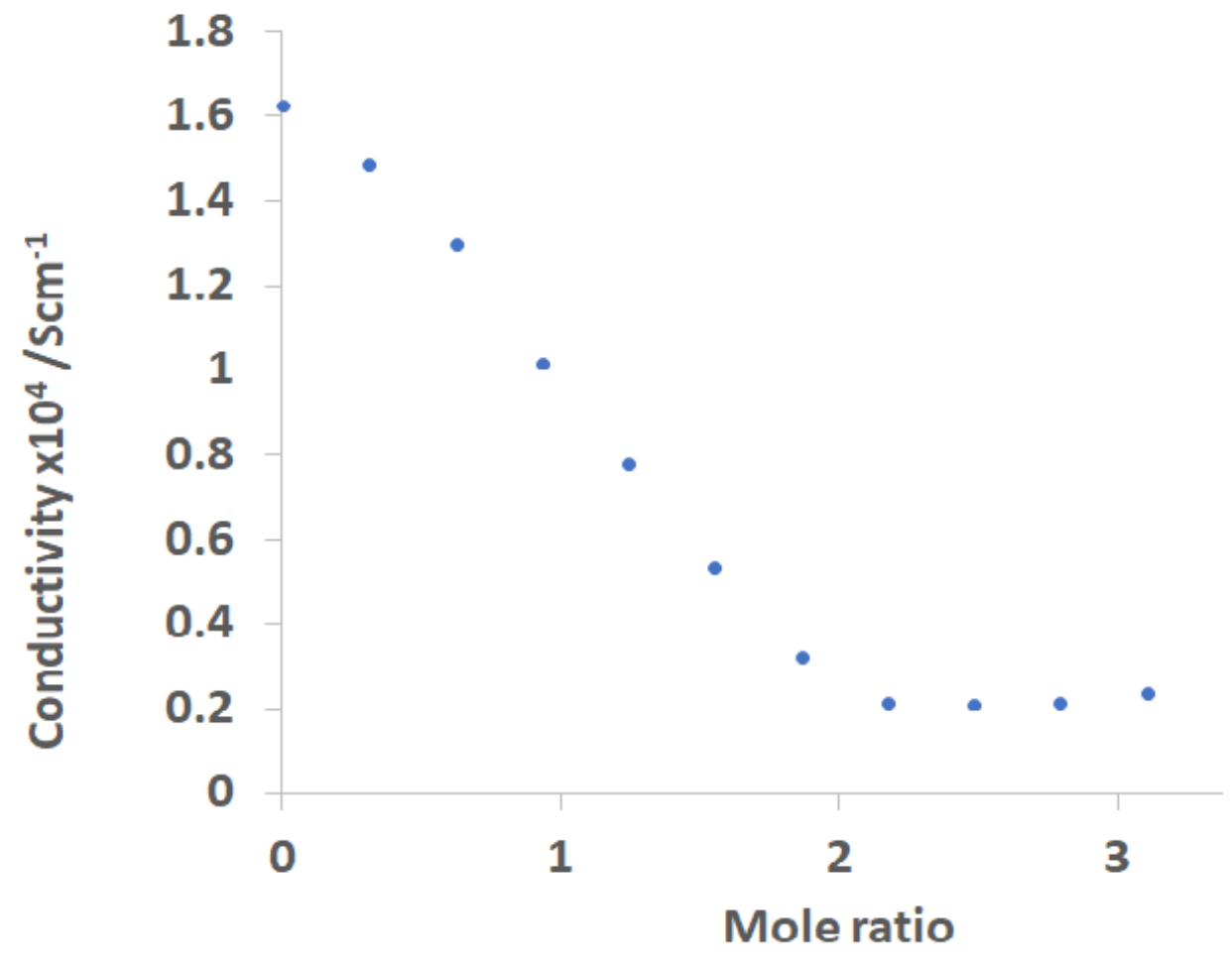

Figure 2 Conductivity $0.02 \mathrm{M}$ CAN vs $\mathrm{Bu}_{3} \mathrm{PO}$ in acetone

The reaction of solutions of $\mathrm{R}_{3} \mathrm{PO}$ in $\mathrm{CDCl}_{3}$ with an excess (CAN: $\mathrm{R}_{3} \mathrm{PO}>4: 1$ ) of solid CAN become yellow / orange in colour soon after mixing. The 31-P NMR spectra clearly indicate the formation of Ce(IV) complexes giving sharper lines at significantly different chemical shifts to the either the analogous $\mathrm{Ce}(\mathrm{III})$ complexes or the unreacted $\mathrm{R}_{3} \mathrm{PO}$. The 31-P NMR data are shown in Table 1 and the 13-C data are given in Table S1. In the initial stages of the reaction when $\mathrm{R}_{3} \mathrm{PO}$ was in excess two separate signals were seen in the 31-P spectra due to the Ce(IV) complex and unreacted ligand showing that exchange between the two is not rapid on the NMR timescale at $20^{\circ} \mathrm{C}$.

Biphasic reactions between aqueous solutions of $C A N$ and chloroform solutions of $R_{3} P O$ proceed rapidly on mixing giving spectra identical to those obtained from the $\mathrm{R}_{3} \mathrm{PO} /$ solid CAN systems. The exchange reaction between chloroform solutions of $\operatorname{Ln}\left(\mathrm{NO}_{3}\right)_{3}\left(\mathrm{R}_{3} \mathrm{PO}\right)_{3}$ and either solid or aqueous solutions of CAN gives $\mathrm{Ce}$ (IV) phosphine oxide complexes with identical chemical shifts to those found using the other methods described above. In this case there is no rapid exchange between $\operatorname{Ln}\left(\mathrm{NO}_{3}\right)_{3}\left(\mathrm{R}_{3} \mathrm{PO}\right)_{3}$ which generally have very large line widths and the $\mathrm{Ce}(\mathrm{IV})$ complexes. 


\begin{tabular}{|l|l|l|l|}
\hline \multicolumn{5}{|c|}{ Table 1 } \\
\hline \multicolumn{3}{|l|}{ 31-P NMR data for the cerium(III) and cerium(IV) complexes in $\mathrm{CDCl}_{3}$} \\
\hline $\mathrm{R}$ & $\mathrm{Ce}\left(\mathrm{NO}_{3}\right)_{4}\left(\mathrm{R}_{3} \mathrm{PO}\right)_{2}$ & $\mathrm{Ce}\left(\mathrm{NO}_{3}\right)_{3}\left(\mathrm{R}_{3} \mathrm{PO}\right)_{3}$ & $\mathrm{R}_{3} \mathrm{PO}$ \\
\hline Et & 79.9 & $100.8^{\mathrm{a}}$ & 53.2 \\
\hline iPr & 86.7 & $109.7^{\mathrm{b}}$ & 60.8 \\
\hline nBu & 75.4 & & 49.2 \\
\hline iBu & 76.0 & $91.2^{\mathrm{c}}$ & 46.9 \\
\hline tBu & 74.0 & $94.8^{\mathrm{d}}$ & 66.6 \\
\hline Cy & 78.5 & 101.5 & 51.7 \\
\hline Oct & 75.1 & & 49.1 \\
\hline
\end{tabular}

a. Data from ref 7, b. data from ref 8, c. data from ref 9 , d. data from ref 10

Attempts to prepare ionic complexes with other counterions were made by reaction of $C A N / \mathrm{R}_{3} \mathrm{PO} / \mathrm{KPF} \mathrm{F}_{6}$, CAN / $\mathrm{R}_{3} \mathrm{PO} / \mathrm{NaBPh}_{4}$ were not successful.

\section{Solid State study}

The complex $\mathrm{Ce}\left(\mathrm{NO}_{3}\right)_{4}\left(\mathrm{Cy}_{3} \mathrm{PO}\right)_{2}$ was prepared by the biphasic reaction of aqueous $\mathrm{CAN}$ and chloroform solution of $\mathrm{Cy}_{3} \mathrm{PO}$ and isolated by cooling a chloroform / diethyl ether mixture giving the product as yellow needles which were suitable for $x$-ray crystal structure determination.

Details of the data collection and refinement are given as supplementary information and selected bond lengths and angles in Table S2. ORTEP plots showing the thermal motion at 50\% probability level are also given in the supplementary information. Two views of the structure are shown in Figure 3.

The overall geometry is similar to that reported for the $\mathrm{Ph}_{3} \mathrm{PO}$ complex [3] with an equatorial belt of bidentate nitrates and axial phosphine oxides giving a coordination number of 10 . Analysis of the geometry of the coordination polyhedron was carried out by continuous shape measures [11] using the SHAPE programme [12]. This gives an objective measure of the deviation of the structure from idealised polyhedral for the given coordination number, and in this case gives a bicapped square antiprism as the 
best description of the structure with the square planes defined by $01,03,06$ and 07 with 04 capping.

The two planes are almost parallel with an angle between them of $1.5^{\circ}$.

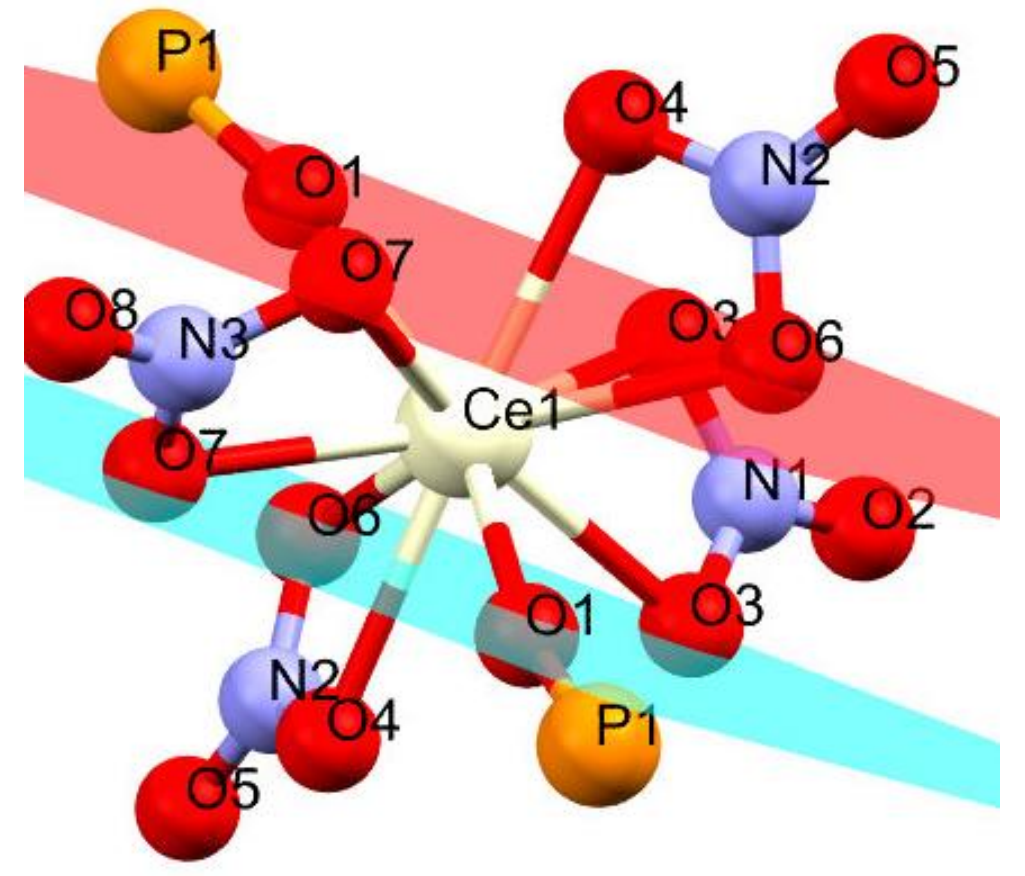

A

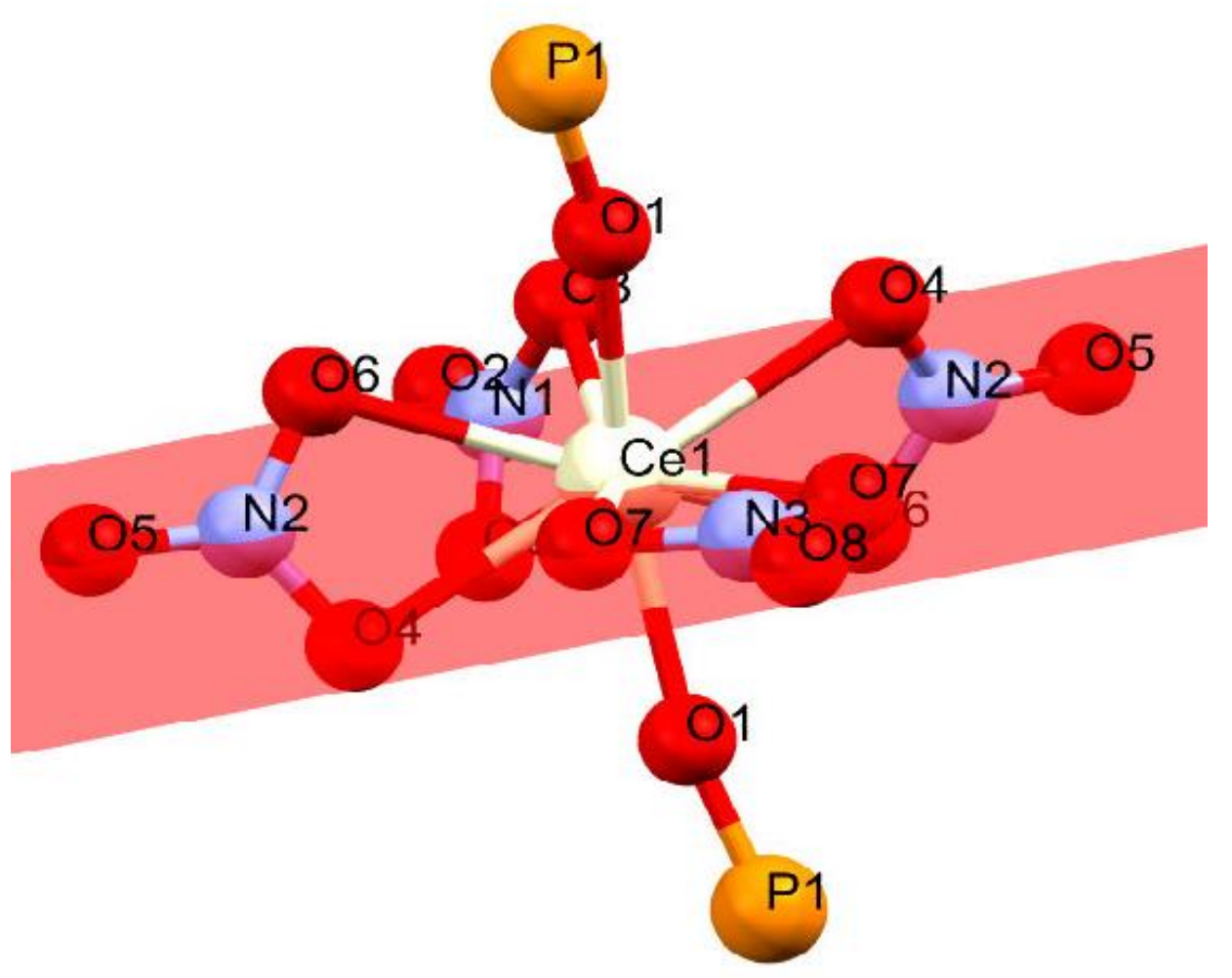


Figure 3 Two views of the structure of $\mathrm{Ce}\left(\mathrm{NO}_{3}\right)_{4}\left(\mathrm{C}_{3} \mathrm{PO}\right)_{2}$ (cyclohexyl groups omitted for clarity) A showing the bicapped square antiprismatic geometry and B a pseudo octahedral geometry

The complex is rather more symmetrical than $\mathrm{Ce}\left(\mathrm{NO}_{3}\right)_{4}\left(\mathrm{Ph}_{3} \mathrm{PO}\right)_{2}$ in that the $4 \mathrm{~N}$-atoms, the cerium ion and the terminal oxygen atoms of all nitrates are all coplanar as indicted in Figure 2B. One of the nitrate groups lies entirely in the CeN4 plane whilst the others are twisted with an angle of about $70^{\circ}$ between the CeN4 and NO3 planes. The average Ce-O(P) distance at $2.239 \AA$ is slightly longer than $2.219 \AA$ for the $\mathrm{Ph}_{3} \mathrm{PO}$ complex, probably due to the increased steric hindrance of the cyclohexyl groups which balances the probable increase in negative charge at the oxygen of $\mathrm{Cy}_{3} \mathrm{PO}$ compared to $\mathrm{Ph}_{3} \mathrm{PO}$. The distances to the nitrate oxygen atoms are essentially the same. The corresponding distances in the $\mathrm{Ce}(\mathrm{III})$ complexes show the trend expected with $\mathrm{Ce}-\mathrm{O}(\mathrm{P})$ distances shorter in the $\mathrm{Cy}_{3} \mathrm{PO}$ complex with the $\mathrm{Ce}-\mathrm{O}(\mathrm{N})$ distances being the same as for the $\mathrm{Ph}_{3} \mathrm{PO}$ complex. Compared to the $\mathrm{Ce}$ (III) derivative the $\mathrm{Ce}-\mathrm{O}$ distances are all shorter as expected from the smaller ionic radius of $\mathrm{Ce}(\mathrm{IV})$ compared to $\mathrm{Ce}(\mathrm{III})$.

Table 2

Comparison of selected average bond distances (Å) and angles in $\mathrm{Ce}(\mathrm{IV})$ and $\mathrm{Ce}$ (III) complexes $^{\mathrm{a}}$

\begin{tabular}{|l|l|l|l|l|}
\hline & $\mathrm{Ce}\left(\mathrm{NO}_{3}\right)_{4}\left(\mathrm{Ph}_{3} \mathrm{PO}\right)_{2}{ }^{\mathrm{b}}$ & $\mathrm{Ce}\left(\mathrm{NO}_{3}\right)_{4}\left(\mathrm{Cy}{ }_{3} \mathrm{PO}\right)_{2}{ }^{\mathrm{c}}$ & $\mathrm{Ce}\left(\mathrm{NO}_{3}\right)_{3}\left(\mathrm{Ph}_{3} \mathrm{PO}\right)_{3}{ }^{\mathrm{d}}$ & $\mathrm{Ce}\left(\mathrm{NO}_{3}\right)_{3}\left(\mathrm{Cy}{ }_{3} \mathrm{PO}\right)_{3}{ }^{\mathrm{c}}$ \\
\hline $\mathrm{Ce}-\mathrm{O}(\mathrm{P})$ & $2.219(4)$ & $2.239(0)$ & $2.414(11)$ & $2.391(1)$ \\
\hline $\mathrm{Pe}-\mathrm{O}(\mathrm{N})$ & $2.478(27)$ & $2.482(14)$ & $2.608(26)$ & $2.597(17)$ \\
\hline $\begin{array}{l}\text { (P)O-Ce-O(P) } \\
\text { Cerium lonic }\end{array}$ & $1.528(3)$ & $1.528(0)$ & $1.487(15)$ & $1.512(7)$ \\
radiie & 1.07 & 157.8 & & \\
\hline
\end{tabular}

a. Values in parenthesis are standard deviations which reflect the variation in bond distances rather than uncertainties in the data collection. b. Data from ref 3, c. this work, d. data from ref 13. e. 10-coordinate radius for Ce(IV) and 9-coordinate radius for $\mathrm{Ce}(\mathrm{III})$ 
The infrared spectra of the Ce(IV) complex show the expected bands due to coordinated nitrate in similar positions to those observed in $\mathrm{Ce}\left(\mathrm{NO}_{3}\right)_{3}\left(\mathrm{C}_{3} \mathrm{PO}\right)_{3}$. The splitting of $\mathrm{v}_{3}$ is increased from 31 to $69 \mathrm{~cm}^{-1}$ which are seen as intense bands at 1446 and $1514 \mathrm{~cm}^{-1}$. The PO stretch is at considerably reduced wavenumber in the $\mathrm{Ce}(\mathrm{IV})$ complex, $1019 \mathrm{~cm}^{-1}$ compared to $1095 \mathrm{~cm}^{-1}$ in $\mathrm{Ce}\left(\mathrm{NO}_{3}\right)_{3}\left(\mathrm{Cy}_{3} \mathrm{PO}\right)_{3}$ consistent with the longer $\mathrm{P}$ $\mathrm{O}$ bond (the $\mathrm{P}-\mathrm{O}$ stretch in the free ligand is at $1146 \mathrm{~cm}^{-1}$ ).

Attempts to isolate complexes with less sterically demanding phosphine oxides by this biphasic reaction method were not successful. Reaction aqueous solution of CAN with chloroform solution of $\mathrm{Et}_{3} \mathrm{PO}$ led to the formation of $\mathrm{Ce}\left(\mathrm{NO}_{3}\right)_{4}\left(\mathrm{Et}_{3} \mathrm{PO}\right)_{2}$ in the organic layer (31-P NMR evidence). Separation of the layers followed dry drying $\left(\mathrm{MgSO}_{4}\right)$ and evaporation led to an oil which could not be crystallised by normal methods. On prolonged standing this oil partially solidified and crystals suitable for $x$-ray diffraction studies could be extracted from it. The crystals were the $\mathrm{Ce}(\mathrm{III})$ complex $\mathrm{Ce}\left(\mathrm{NO}_{3}\right)_{3}\left(\mathrm{H}_{2} \mathrm{O}\right)_{3}\left(\mathrm{Et} \mathrm{t}_{3} \mathrm{PO}\right)$ the structure of which is shown in Figure 4. The coordinated water molecules arise as a result of the preparative method. The complex can be considered as a distorted pentagonal bipyramid if the nitrate ligands are thought of as pseudo monodentate ligands bonded through the nitrogen atom. 


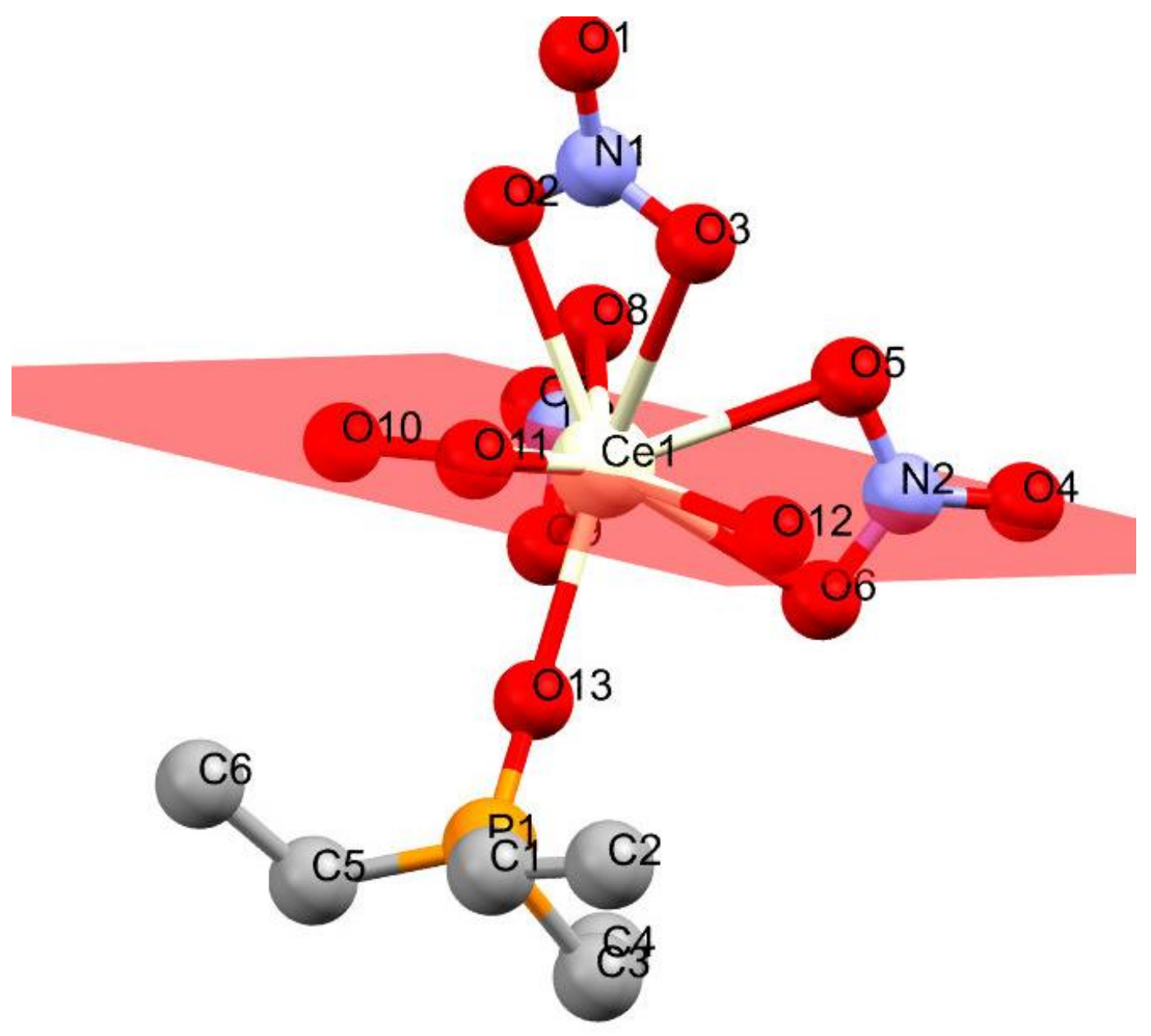

Figure 4 The structure of $\mathrm{Ce}\left(\mathrm{NO}_{3}\right)_{3}\left(\mathrm{H}_{2} \mathrm{O}\right)_{3}\left(\mathrm{Et}_{3} \mathrm{PO}\right)$ (hydrogen atoms omitted for clarity)

The equatorial plane is defined by the two remaining nitrate nitrogen atoms and the three water oxygen atoms. The bond distances compare well with those observed in the structure of $\mathrm{Ce}\left(\mathrm{NO}_{3}\right)_{3}\left(\mathrm{Et}_{3} \mathrm{PO}\right)_{3}$ and are shown in Table 3. All the bond distances agree well with those observed in $\mathrm{Ce}\left(\mathrm{NO}_{3}\right)_{3}\left(\mathrm{Et}_{3} \mathrm{PO}\right)_{3}$.

Reaction of chloroform solutions of $\mathrm{R}_{3} \mathrm{PO}$ with solid CAN gave $\left[\mathrm{Ce}\left(\mathrm{NO}_{3}\right)_{4}\left(\mathrm{R}_{3} \mathrm{PO}\right)_{2}\right]$ as the only phosphorus containing species in solution. Evaporation of these solutions produced viscous intractable oils for which only modest to poor elemental analysis could be obtained. The triethylphosphine oxide complex was studied in more detail. Exhaustive attempts to produce crystalline solids using a variety of techniques failed. On prolonged standing the oil gave a small amount of crystalline material which could be mechanically extracted from the viscous oil and were suitable for $x$-ray diffraction. These crystals were the ionic complex $\left[\mathrm{Ce}\left(\mathrm{NO}_{3}\right)_{3}\left(\mathrm{Et}_{3} \mathrm{PO}\right)_{3}\right]^{+}\left[\mathrm{NO}_{3}\right]^{-}$, the cation of which has a pseudo-octahedral geometry taking the nitrates as monodentate ligands attached via the nitrogen atoms. The structure is shown in Figure 5. There are voids (channels) in the structure of about $360 \AA^{3}$ and the ionic nitrate was not refined. However, 
the infrared spectrum clearly indicates the presence of ionic as well as coordinated nitrates. Intense absorptions at $1507,1432,1317$ and $1263 \mathrm{~cm}^{-1}$ are assigned to coordinated bidentate nitrates and a medium intensity peak at $1403 \mathrm{~cm}^{-1}$ to ionic nitrate. The large splitting in $v_{3}$ is again observed and together with the large overall splitting of the nitrate absorptions seems to be a characteristic feature of the spectra of $\mathrm{Ce}(\mathrm{IV})$ nitrate complexes.

Analysis by continual shape measures gives a tricapped trigonal prism as the best description of the geometry around the $\mathrm{Ce}$ ion. The triangular faces, formed by the $\mathrm{O} 1$ oxygen atoms and the $\mathrm{O} 4$ atoms from the phosphine oxides, are parallel. The capping atoms are $\mathrm{O} 2$ from the nitrates and the angles between the square faces at $60.04^{\circ}$ correspond closely to the idealised angles of $60^{\circ}$.

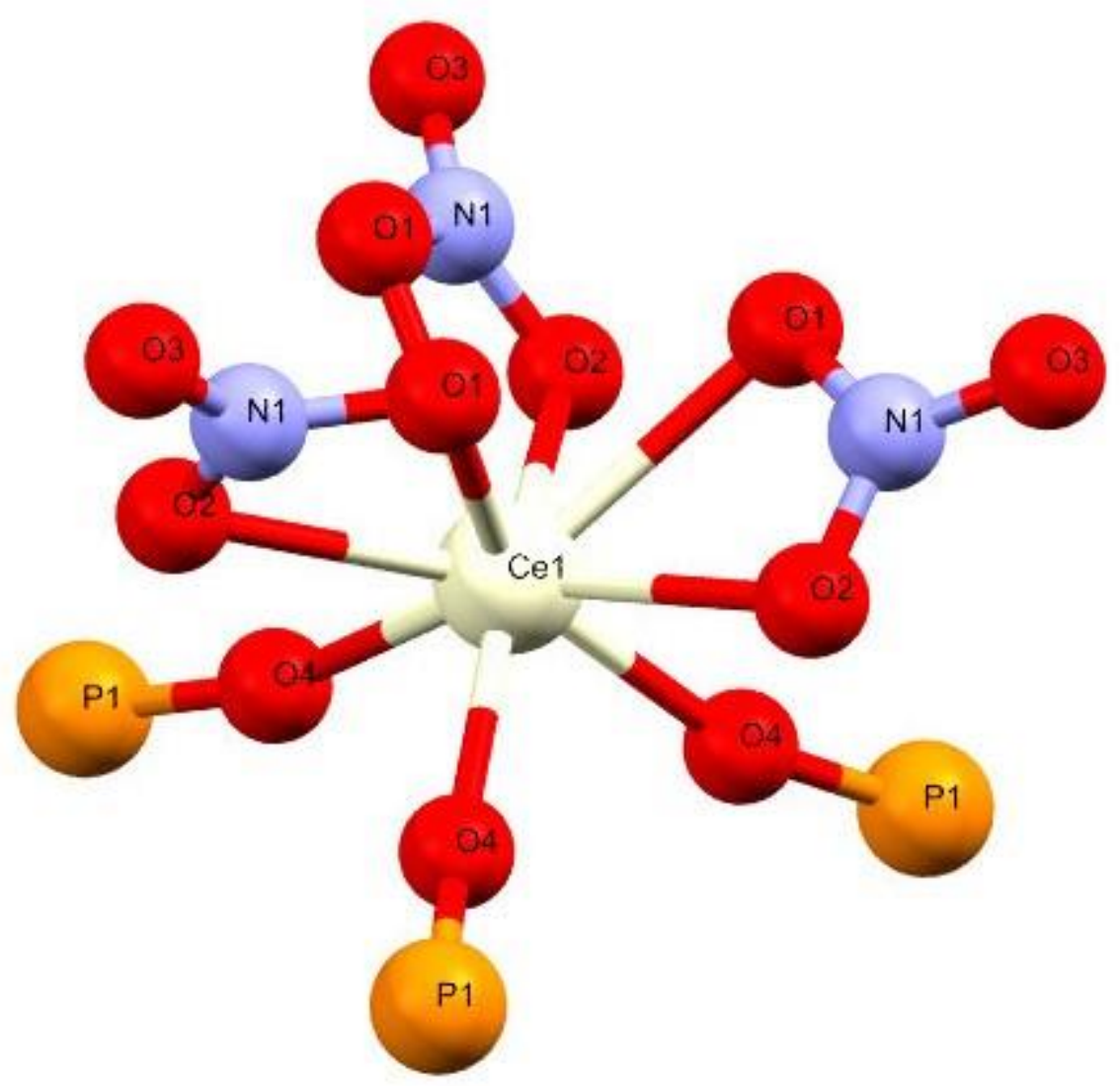

Figure 5 The structure of the $\left[\text { fac- } \mathrm{Ce}\left(\mathrm{NO}_{3}\right)_{3}\left(\mathrm{Et}_{3} \mathrm{PO}\right)_{3}\right]^{+}$cation (ethyl groups omitted for clarity)

Selected bond distances are compared with those of mer- $\mathrm{Ce}\left(\mathrm{NO}_{3}\right)_{3}\left(\mathrm{Et}_{3} \mathrm{PO}\right)_{3}[8]$ and $\mathrm{Ce}\left(\mathrm{NO}_{3}\right)_{3}\left(\mathrm{H}_{2} \mathrm{O}\right)_{3}\left(\mathrm{Et}{ }_{3} \mathrm{PO}\right)$ in Table 3. All the bonds to $\mathrm{Ce}$ in $\left[\mathrm{fac}-\mathrm{Ce}\left(\mathrm{NO}_{3}\right)_{3}\left(\mathrm{Et}_{3} \mathrm{PO}\right)_{3}\right]^{+}$are significantly shorter than in mer$\mathrm{Ce}\left(\mathrm{NO}_{3}\right)_{3}\left(\mathrm{Et}_{3} \mathrm{PO}\right)_{3}$ which implies the compound is actually $\mathrm{Ce}(\mathrm{IV})$ rather than $\mathrm{Ce}(\mathrm{III})$. 


\begin{tabular}{|c|c|c|c|}
\hline \multicolumn{4}{|c|}{ Comparison of selected average bond distances in $\mathrm{Ce}(\mathrm{III})$ and $\mathrm{Ce}(\mathrm{IV}) \mathrm{Et}_{3} \mathrm{PO}$ complexes with } \\
\hline & {$\left[\mathrm{fac}-\mathrm{Ce}\left(\mathrm{NO}_{3}\right)_{3}\left(\mathrm{Et}_{3} \mathrm{PO}\right)_{3}\right]^{+}$} & $m e r-\mathrm{Ce}\left(\mathrm{NO}_{3}\right)_{3}\left(\mathrm{Et}_{3} \mathrm{PO}\right)_{3}{ }^{\mathrm{b}}$ & $\mathrm{Ce}\left(\mathrm{NO}_{3}\right)_{3}\left(\mathrm{H}_{2} \mathrm{O}\right)_{3}\left(\mathrm{Et}_{3} \mathrm{PO}\right)$ \\
\hline $\mathrm{Ce}-\mathrm{O}(\mathrm{P})$ & $2.199(1)^{a}$ & $2.374(17)$ & 2.317 \\
\hline $\mathrm{Ce}-\mathrm{O}(\mathrm{N})$ & $2.483(26)$ & $2.605(21)$ & $2.651(26)$ \\
\hline P-O & $1.530(0)$ & $1.499(7)$ & 1.504 \\
\hline$B V S+3^{c}$ & 4.66 & 3.12 & 3.03 \\
\hline BVS $+4^{c}$ & 4.09 & 2.74 & 2.67 \\
\hline
\end{tabular}

a. Values in parenthesis are standard deviations which reflect the variation in bond distances rather than the data collection. b. data from ref 7 c. from ref $12 B V S+3=\sum_{i} e^{(2.188-r i) / 0.37} B V S+4=\sum_{i} e^{(2.07-r i) / 0.37}$

Bond valence sums (BVS) [14] provide a method of estimating the oxidation state in cases where there is ambiguity from the structural data such as here where the anion is disordered or where the hydrogen atoms of coordinated water molecules or hydroxide may be difficult to detect. The calculated bond valence sums for both +3 and +4 oxidation states are given in Table 3 . The values of BVS were calculated on the basis of the oxidation state being either +3 or +4 and both results are presented in the table. The sum should closely match the true oxidation state and clearly show that the $\left[\mathrm{Ce}\left(\mathrm{NO}_{3}\right)_{3}\left(\mathrm{Et}_{3} \mathrm{PO}\right)_{3}\right]^{+}$is correctly formulated as $\mathrm{Ce}(\mathrm{IV})$ and $\mathrm{Ce}\left(\mathrm{NO}_{3}\right)_{3}\left(\mathrm{H}_{2} \mathrm{O}\right)_{3}\left(\mathrm{Et} \mathrm{t}_{3} \mathrm{PO}\right)$ as $\mathrm{Ce}(\mathrm{III})$. 


\section{Conclusion}

Cerium(IV) complexes of trialkylphosphine oxides can be readily formed in solution although isolation has proved to be difficult for all but the tricyclohexylphosphine oxide complex. Analysis of structures using bond valence sums has provided a means of assigning oxidation states in cases where the structural data is ambiguous and shown that cationic cerium(IV) species can be formed. The geometries around the cerium ion were found to be best described as a bicapped square antiprism for $\mathrm{Ce}\left(\mathrm{NO}_{3}\right)_{4}\left(\mathrm{C} \mathrm{y}_{3} \mathrm{PO}\right)_{2}$ and a tricapped trigonal prism for $\left[\mathrm{Ce}\left(\mathrm{NO}_{3}\right)_{3}\left(\mathrm{Et}_{3} \mathrm{po}\right)_{3}\right]^{+}$. Attempts to isolate cationic complexes as the $\mathrm{PF}_{6}{ }^{-}$or $\mathrm{BPh}_{4}{ }^{-}$salts was not successful.

\section{Experimental}

NMR spectra were recorded in $\mathrm{CDCl}_{3}$ solution on a JEOL ECX 400, approximately $20 \mathrm{mg}$ of solid in $1 \mathrm{~mL}$ of the appropriate deuterated solvent.

Infrared spectra were recorded with a resolution of $\pm 1 \mathrm{~cm}^{-1}$ on a Thermo Nicolet Avatar $370 \mathrm{FT}$-IR spectrometer operating in ATR mode. The samples were compressed onto the optical window and spectra recorded without further sample pre-treatment.

\section{X-Ray crystallography}

Full details of the data collection and refinement are given as supplementary information. Crystallographic data (excluding structure factors) for the structures in this paper have been deposited with the Cambridge Crystallographic Data Centre as supplementary publication numbers 1879338, 1879342, 187943 and 1879350 for $\mathrm{Ce}\left(\mathrm{NO}_{3}\right)_{4}\left(\mathrm{Cy} \mathrm{P}_{3} \mathrm{PO}\right)_{2}, \mathrm{Ce}\left(\mathrm{NO}_{3}\right)_{3}\left(\mathrm{H}_{2} \mathrm{O}\right)_{3}\left(\mathrm{Et}{ }_{3} \mathrm{PO}\right),\left[\mathrm{Ce}\left(\mathrm{NO}_{3}\right)_{3}\left(\mathrm{Et}_{3} \mathrm{PO}\right)_{3}\right]\left[\mathrm{NO}_{3}\right]$ and $\mathrm{Ce}\left(\mathrm{NO}_{3}\right)_{3}\left(\mathrm{Cy}{ }_{3} \mathrm{PO}\right)_{3}$ respectively. Copies of the data can be obtained, free of charge, on application to CCDC, 12 Union Road, Cambridge CB2 1EZ, UK (Fax: p44(0)-1223-336033 or e-mail: deposit@ccdc.cam.ac.uk

\section{Synthesis}

$\mathrm{Ce}\left(\mathrm{NO}_{3}\right)_{4}\left(\mathrm{Cy}_{3} \mathrm{PO}\right)_{2}$ An excess of $\mathrm{CAN}(0.45 \mathrm{~g} 0.82 \mathrm{mmol})$ in $2.5 \mathrm{~mL}$ water were stirred with a solution of $\mathrm{Cy}_{3} \mathrm{PO}(0.24 \mathrm{~g} 0.81 \mathrm{mmol})$ in $1.8 \mathrm{~mL}$ of chloroform for 10 minutes. The orange chloroform layer was 
separated, dried $\left(\mathrm{MgSO}_{4}\right)$, filtered and mixed with an equal volume of diethylether. Cooling to $-30^{\circ} \mathrm{C}$ gave yellow needles suitable for $x$-ray crystallography ( $0.19 \mathrm{~g} 46 \%$ based on $\left.\mathrm{Cy}_{3} \mathrm{PO}\right)$. Analysis (\%) Expected (found): C 44.08 (44.92) H6.78 (6.73) N 5.71 (5.69)

$\mathrm{Ce}\left(\mathrm{NO}_{3}\right)_{4}\left(\mathrm{Et} \mathrm{P}_{3} \mathrm{PO}\right)_{2} ; \mathrm{CAN}(92.0 \mathrm{mg} 0.17 \mathrm{mmol})$ was suspended with $\mathrm{Et}_{3} \mathrm{PO}(29.8 \mathrm{mg} 0.22 \mathrm{mmol})$ in $0.6 \mathrm{~mL}$ $\mathrm{CDCl}_{3}$. After the 31-P NMR spectrum indicated complete reaction the solution was filtered evaporated to dryness and the resulting yellow oil dried in vacuo over $\mathrm{KOH}$ to give $38.6 \mathrm{mg}(53 \%)$.

On standing the oil partially solidified and crystals of $\left[\mathrm{Ce}\left(\mathrm{NO}_{3}\right)_{3}\left(\mathrm{Et}_{3} \mathrm{PO}\right)_{3}\right]\left[\mathrm{NO}_{3}\right]$ suitable for $x$-ray diffraction studies were mechanically removed. There was insufficient material for elemental analysis.

$\operatorname{NMR}\left(\mathrm{CDCl}_{3}\right)$ 31-P $\left.\delta 79.9 \mathrm{ppm} 13-\mathrm{C} \mathrm{CH}_{3} \delta 4.95, \delta\left(\delta,{ }^{2} \mathrm{~J}_{\mathrm{PC}}=4.7 \mathrm{~Hz}\right), \mathrm{CH}_{2} 18.359 \mathrm{~d},{ }^{1} \mathrm{JPC}_{\mathrm{PC}}=65.1 \mathrm{~Hz}\right)$

Analysis (\%) Expected (found): C 22.96 (23.44) H 4.61 (4.89) N 8.54 (7.65)

$\mathrm{Ce}\left(\mathrm{NO}_{3}\right)_{4}\left(\mathrm{Bu}_{3} \mathrm{PO}\right)_{2} ; \mathrm{CAN}(69.8 \mathrm{mg} 0.13 \mathrm{mmol})$ was suspended with $\mathrm{Bu}_{3} \mathrm{PO}(34.4 \mathrm{mg} 0.16 \mathrm{mmol})$ in $0.6 \mathrm{~mL}$ $\mathrm{CDCl}_{3}$. After $6 \mathrm{~d}$ the 31-P NMR spectrum indicated complete reaction. The solution was filtered evaporated to dryness and the resulting yellow oil dried in vacuo over $\mathrm{KOH}$ to give $44.1 \mathrm{mg}$ (67 \%).

NMR $\left(\mathrm{CDCl}_{3}\right)$ 31-P $\delta 75.4$ ppm 13- $\mathrm{C} \mathrm{CH}_{3} \delta 13.46(\mathrm{~s}), \mathrm{CH}_{2} \delta 22.95\left(\mathrm{~d},{ }^{2} \mathrm{~J}_{\mathrm{PC}}=3.8 \mathrm{~Hz}\right), \mathrm{CH}_{2} \delta 24.03\left(\mathrm{~d},{ }^{3} \mathrm{~J}_{\mathrm{PC}}=15.4\right.$ $\mathrm{Hz}), \mathrm{CH}_{2} \delta 25.79\left(\mathrm{~d},{ }^{1} \mathrm{~J}_{\mathrm{PC}}=63.0 \mathrm{~Hz}\right)$

Analysis (\%) Expected (found): C 34.95 (38.18) H 6.60 (6.71) N 6.79 (7.65)

$\mathrm{Ce}\left(\mathrm{NO}_{3}\right)_{4}\left(\mathrm{Oct}{ }_{3} \mathrm{PO}\right)_{2}$ CAN $(68.0 \mathrm{mg} 0.12 \mathrm{mmol})$ was suspended with Oct ${ }_{3} \mathrm{PO}(50.0 \mathrm{mg} 0.13 \mathrm{mmol})$ in $0.6 \mathrm{~mL}$ $\mathrm{CDCl}_{3}$. After the 31-P NMR spectrum indicated complete reaction. The solution was filtered, evaporated to dryness and the resulting yellow oil dried in vacuo over $\mathrm{KOH}$ to give $45.0 \mathrm{mg}$ (60\%).

$\operatorname{NMR}\left(\mathrm{CDCl}_{3}\right)$ 31-P $\delta 75.1 \mathrm{ppm} 13-\mathrm{C} \delta 14.16(\mathrm{~s}), \delta 21.01\left(\mathrm{~d},{ }^{2} \mathrm{~J}_{\mathrm{PC}}=3.8 \mathrm{~Hz}\right), \delta 23.20\left(\mathrm{~d},{ }^{1} \mathrm{~J}_{\mathrm{PC}}=63.2 \mathrm{~Hz}\right), \delta$ $28.92(\mathrm{~s}), \delta 29.03(\mathrm{~s}), \delta 30.90\left(\mathrm{~d},{ }^{3} \mathrm{~J}_{\mathrm{PC}}=15.3 \mathrm{~Hz}\right), \delta 31.81(\mathrm{~s})$

Analysis (\%) Expected (found): C 49.64 (53.62) H 8.85 (9.38) N 4.82 (4.57) 
We are grateful to the EPSRC for the use of the National Crystallography Service at Southampton University[15].

\section{References}

1. Y-M. So, W-H. Leung, Coord. Chem. Rev. 340 (2017) 172

2. A.W.G. Platt, Coord. Chem. Rev. 340 (2017) 21

3. M. Ul-Haque, C.N. Caughlin, F.A. Hart, R. vanNice, Inorg. Chem. 10 (1971) 115

4. R. Babecki, A.W.G. Platt and R.R. Russell, Inorg. Chim. Acta 171 (1990) 25

5. Y. Koide, A. Sakamoto, T. Imamoto, T. Tanase, Y. Yamamoto, J. Alloys Compnd. 192 (1993) 211

6. P-Y Jiang, Y. Ikeda, M. Kumagai J. Nucl. Sci. Tech. 31 (1994) 491

7. A. Bowden, K. Singh, A.W.G. Platt, Polyhedron 42 (2012) 30

8. A. Bowden, S.J. Coles, M.B. Pitak, A.W.G.Platt, Polyhedron 68 (2014) 258

9. A. Bowden, P.N. Horton, A.W.G. Platt, Inorg. Chem. 50 (2011) 2553

10. A. Bowden, S.J. Coles, M.B. Pitak, A.W.G.Platt, Inorg. Chem. 51 (2012) 4379

11. S.Alvarez, P.Alemany, D.Casanova, J.Cirera, M.Llunell, D.Avnir, Coord. Chem. Rev. 249, (2005), 1693

12. M.Llunell, D.Casanova, J.Cirera, P.Alemany, S.Alvarez, SHAPE - Program for the Stereochemical Analysis of Molecular Fragments by Means of Continuous Shape Measures and Associated Tools, Version 2.1, University of Barcelona, Spain, 2013Shape

13. W. Levason, E.H. Newman, M. Webster, Polyhedron 19 (2000) 2697

14. G.J. Palenik, S-Z. Hu, Inorg. Chim. Acta 362 (2009) 4740

15. S.J.Coles, P.A.Gale, Chem. Sci., 3 (2012) 68 


\section{Crystal Data and Experimental for $\mathrm{Ce}\left(\mathrm{NO}_{3}\right)_{4}\left(\mathrm{Cy}_{3} \mathrm{PO}\right)_{2}$}

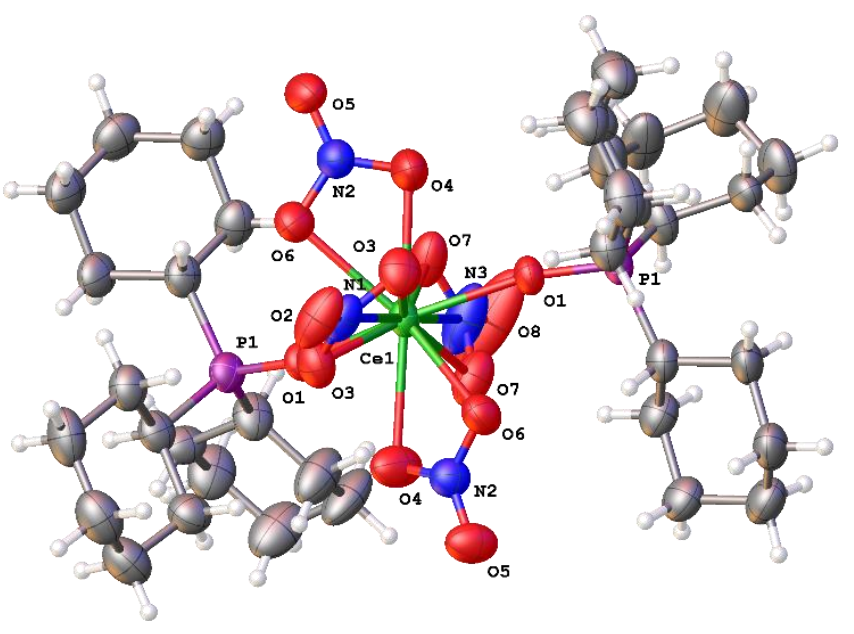

Experimental. Single yellow needle-shaped crystals of (2017ncs0302) were recrystallised from a mixture of chloroform and diethylether by solvent layering. A suitable crystal $(0.300 \times 0.050 \times 0.040) \mathrm{mm}^{3}$ was selected and mounted on a MITIGEN holder in perfluoroether oil on a Rigaku 007HF diffractometer equipped with Varimax confocal mirrors and an AFC11 goniometer and HyPix 6000 detector. The crystal was kept at $T=100$ (2) K during data collection. Using Olex2 (Dolomanov et al., 2009), the structure was solved with the ShelXT (Sheldrick, 2015) structure solution program, using the Intrinsic Phasing solution method. The model was refined with version 2014/7 of ShelXL (Sheldrick, 2015) using Least Squares minimisation.

Crystal Data. $\mathrm{C}_{36} \mathrm{H}_{66} \mathrm{~N}_{4} \mathrm{O}_{14} \mathrm{P}_{2} \mathrm{Ce}, M_{r}=980.98$, monoclinic, C2/c (No. 15), $a=14.8612(4) \AA, b=16.7067(4) \AA, c=$ 18.9890(5) Å, $\quad \beta=109.044(3)^{\circ}, \quad \alpha=\quad \gamma=90^{\circ}, \quad V=$ 4456.6(2) $\AA^{3}, T=100(2) \mathrm{K}, Z=4, Z^{\prime}=0.5, \mu\left(\mathrm{CuK}_{\alpha}\right)=9.127$, 21330 reflections measured, 4197 unique $\left(R_{\text {int }}=0.0545\right)$ which were used in all calculations. The final $w R_{2}$ was 0.1145 (all data) and $R_{1}$ was 0.0409 (I > 2(I)).

\begin{tabular}{|c|c|}
\hline Compound & 2017ncs0302 \\
\hline Formula & $\mathrm{C}_{36} \mathrm{H}_{66} \mathrm{~N}_{4} \mathrm{O}_{14} \mathrm{P}_{2} \mathrm{Ce}$ \\
\hline$D_{\text {calc. }} / \mathrm{g} \mathrm{cm}^{-3}$ & 1.462 \\
\hline$\mu / \mathrm{mm}^{-1}$ & 9.127 \\
\hline Formula Weight & 980.98 \\
\hline Colour & yellow \\
\hline Shape & needle \\
\hline $\mathrm{Size} / \mathrm{mm}^{3}$ & $0.300 \times 0.050 \times 0.040$ \\
\hline$T / \mathrm{K}$ & $100(2)$ \\
\hline Crystal System & monoclinic \\
\hline Space Group & $\mathrm{C} 2 / \mathrm{c}$ \\
\hline$a / \AA$ & $14.8612(4)$ \\
\hline$b / \AA$ & $16.7067(4)$ \\
\hline$c / \AA$ & $18.9890(5)$ \\
\hline$\left.\alpha\right|^{\circ}$ & 90 \\
\hline$\beta /^{\circ}$ & $109.044(3)$ \\
\hline$\left.\gamma\right|^{\circ}$ & 90 \\
\hline $\mathrm{V} / \AA^{3}$ & $4456.6(2)$ \\
\hline$Z$ & 4 \\
\hline$Z^{\prime}$ & 0.5 \\
\hline Wavelength/Å & 1.54184 \\
\hline Radiation type & $\mathrm{CuK}_{\alpha}$ \\
\hline$\Theta_{\min } /^{\circ}$ & 4.112 \\
\hline$\Theta_{\max } /^{\circ}$ & 70.055 \\
\hline Measured Refl. & 21330 \\
\hline Independent Refl. & 4197 \\
\hline Reflections Used & 4010 \\
\hline$R_{\text {int }}$ & 0.0545 \\
\hline Parameters & 260 \\
\hline Restraints & 0 \\
\hline Largest Peak & 1.012 \\
\hline Deepest Hole & -0.970 \\
\hline GooF & 1.134 \\
\hline$w R_{2}$ (all data) & 0.1145 \\
\hline$w R_{2}$ & 0.1136 \\
\hline$R_{1}$ (all data) & 0.0420 \\
\hline$R_{1}$ & 0.0409 \\
\hline
\end{tabular}


Structure Quality Indicators

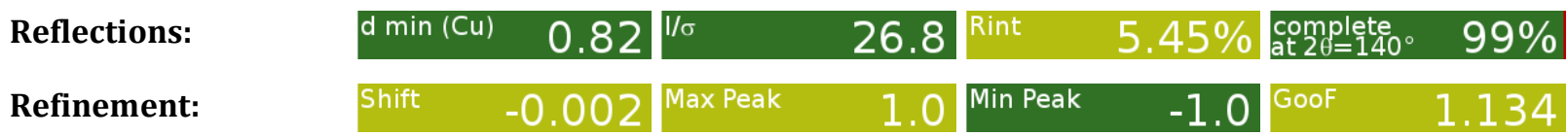

A yellow needle-shaped crystal with dimensions $0.300 \times 0.050 \times 0.040 \mathrm{~mm}^{3}$ was mounted on a MITIGEN holder in perfluoroether oil. X-ray diffraction data were collected using a Rigaku 007HF diffractometer equipped with Varimax confocal mirrors and an AFC11 goniometer and HyPix 6000 detector, and equipped with an Oxford Cryosystems low-temperature device, operating at $T=100(2) \mathrm{K}$.

Data were measured using profile data from $\omega$-scans of $0.5^{\circ}$ per frame for $1.0 \mathrm{~s}$ using $\mathrm{CuK}_{\alpha}$ radiation (Rotating anode, $40.0 \mathrm{kV}, 30.0 \mathrm{~mA}$ ). The total number of runs and images was based on the strategy calculation from the program CrysAlisPro (Rigaku, V1.171.39.9g, 2015). The maximum resolution achieved was $\Theta=70.055^{\circ}$.

Cell parameters were retrieved using the CrysAlisPro (Rigaku, V1.171.39.9g, 2015) software and refined using CrysAlisPro (Rigaku, V1.171.39.9g, 2015) on 14528 reflections, $68 \%$ of the observed reflections.

Data reduction was performed using the CrysAlisPro (Rigaku, V1.171.39.9g, 2015) software which corrects for Lorentz polarisation. The final completeness is $99.90 \%$ out to $70.055^{\circ}$ in $\Theta$. The absorption coefficient $\mu$ of this material is $9.127 \mathrm{~mm}^{-1}$ at this wavelength $(\lambda=1.54184 \AA)$ and the minimum and maximum transmissions are 0.56461 and 1.00000.

The structure was solved in the space group C2/c (\# 15) by Intrinsic Phasing using the ShelXT (Sheldrick, 2015) structure solution program and refined by Least Squares using version 2014/7 of ShelXL (Sheldrick, 2015). All non-hydrogen atoms were refined anisotropically. Hydrogen atom positions were calculated geometrically and refined using the riding model.

_exptl_absorpt_process_details: CrysAlisPro 1.171.39.9g (Rigaku Oxford Diffraction, 2015)Empirical absorption correction using spherical harmonics, implemented in SCALE3 ABSPACK scaling algorithm. 


\section{Crystal Data and Experimental for $\mathrm{Ce}\left(\mathrm{NO}_{3}\right)_{3}\left(\mathrm{H}_{2} \mathrm{O}\right)_{3}\left(\mathrm{Et}_{3} \mathrm{PO}\right)$}

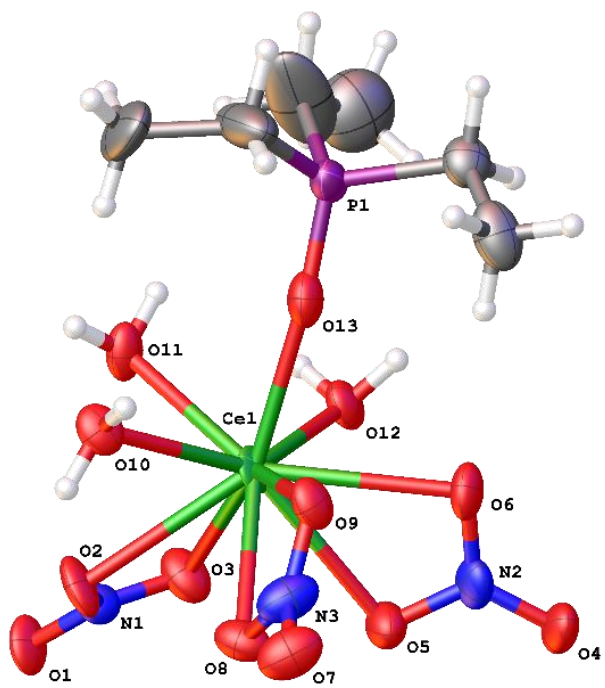

Figure 1: Thermal ellipsoids drawn at the $50 \%$ probability level.

Experimental. Single colourless plate-shaped crystals of 2017ncs0512 were obtained by recrystallisation from chloroform. A suitable crystal $(0.050 \times 0.030 \times 0.005) \mathrm{mm}^{3}$ was selected and mounted on a MITIGEN holder in perfluoroether oil on a Rigaku FRE+ diffractometer equipped with VHF Varimax confocal mirrors and an AFC12 goniometer and HyPix 6000 detector. The crystal was kept at $T=100(2) \mathrm{K}$ during data collection. Using Olex2 (Dolomanov et al., 2009), the structure was solved the structure was solved with the ShelXT (Sheldrick, 2015) structure solution program, using the Intrinsic Phasing solution method. The model was refined with version 2014/7 of ShelXL (Sheldrick, 2015) using Least Squares minimisation.

Crystal Data. $\mathrm{C}_{6} \mathrm{H}_{21} \mathrm{~N}_{3} \mathrm{O}_{13} \mathrm{PCe}, M_{r}=514.35$, orthorhombic, Aea2 (No. 41), $a=18.7948(9) \AA, b=13.9783(6) \AA, c=$ 14.0130(5) $\AA, \alpha=\beta=\gamma=90^{\circ}, \quad V=3681.5(3) \AA^{3}, T=$ $100(2) \mathrm{K}, Z=8, Z^{\prime}=1, \mu\left(\mathrm{MoK}_{\alpha}\right)=2.624 \mathrm{~mm}^{-1}, 40394$ reflections measured, 4245 unique $\left(R_{\text {int }}=0.1121\right)$ which were used in all calculations. The final $w R_{2}$ was 0.2031 (all data) and $R_{1}$ was 0.0791 (I > 2(I)).

\begin{tabular}{|c|c|}
\hline Compound & 2017ncs0512 \\
\hline Formula & $\mathrm{C}_{6} \mathrm{H}_{21} \mathrm{~N}_{3} \mathrm{O}_{13} \mathrm{PCe}$ \\
\hline$D_{\text {calc. }} / \mathrm{g} \mathrm{cm}^{-3}$ & 1.856 \\
\hline$\mu / \mathrm{mm}^{-1}$ & 2.624 \\
\hline Formula Weight & 514.35 \\
\hline Colour & colourless \\
\hline Shape & plate \\
\hline $\mathrm{Size} / \mathrm{mm}^{3}$ & $0.050 \times 0.030 \times 0.005$ \\
\hline$T / \mathrm{K}$ & $100(2)$ \\
\hline Crystal System & orthorhombic \\
\hline Flack Parameter & $0.007(16)$ \\
\hline Hooft Parameter & $0.033(11)$ \\
\hline Space Group & Aea2 \\
\hline$a / \AA$ & $18.7948(9)$ \\
\hline$b / \AA$ & $13.9783(6)$ \\
\hline$c / \AA$ & $14.0130(5)$ \\
\hline$\alpha /^{\circ}$ & 90 \\
\hline$\beta /^{\circ}$ & 90 \\
\hline$\left.\gamma\right|^{\circ}$ & 90 \\
\hline $\mathrm{V} / \AA^{3}$ & $3681.5(3)$ \\
\hline$Z$ & 8 \\
\hline$Z^{\prime}$ & 1 \\
\hline Wavelength/Å & 0.71075 \\
\hline Radiation type & $\operatorname{MoK}_{\alpha}$ \\
\hline$\Theta_{\min } /^{\circ}$ & 2.167 \\
\hline$\Theta_{\max } /^{\circ}$ & 27.484 \\
\hline Measured Refl. & 40394 \\
\hline Independent Refl. & 4245 \\
\hline Reflections Used & 4064 \\
\hline$R_{\text {int }}$ & 0.1121 \\
\hline Parameters & 223 \\
\hline Restraints & 1 \\
\hline Largest Peak & 4.848 \\
\hline Deepest Hole & -2.853 \\
\hline GooF & 1.115 \\
\hline$w R_{2}$ (all data) & 0.2031 \\
\hline$w R_{2}$ & 0.2016 \\
\hline$R_{1}$ (all data) & 0.0815 \\
\hline$R_{1}$ & 0.0791 \\
\hline
\end{tabular}


Structure Quality Indicators

\section{Reflections: \\ $\mathrm{d} \min (\mathrm{Mo}) \quad 0.77$ \\ $1 / \sigma \quad 17.0$ \\ Rint $\quad 11.21 \%$ \\ complate $\quad 100 \%$ \\ Refinement:

Shift $\quad 0.000$ Max Peak $\quad 4.8$ Min Peak -2.9 \\ $1.1150 .007(16)$}

A colourless plate-shaped crystal with dimensions $0.050 \times 0.030 \times 0.005 \mathrm{~mm}^{3}$ was mounted on a MITIGEN holder in perfluoroether oil. X-ray diffraction data were collected using a Rigaku FRE+ diffractometer equipped with VHF Varimax confocal mirrors and an AFC12 goniometer and HyPix 6000 detector and equipped with an Oxford Cryosystems low-temperature device, operating at $T=100(2) \mathrm{K}$.

Data were measured using profile data from $\omega$-scans of $0.5^{\circ}$ per frame for $15.0 \mathrm{~s}$ using $\mathrm{MoK}_{\alpha}$ radiation (Rotating Anode, $45.0 \mathrm{kV}, 55.0 \mathrm{~mA}$ ). The total number of runs and images was based on the strategy calculation from the program CrysAlisPro (Rigaku, V1.171.39.30d, 2017). The maximum resolution achieved was $\Theta=27.484^{\circ}$.

Cell parameters were retrieved using the CrysAlisPro (Rigaku, V1.171.39.30d, 2017) software and refined using CrysAlisPro (Rigaku, V1.171.39.30d, 2017) on 9800 reflections, $24 \%$ of the observed reflections.

Data reduction was performed using the CrysAlisPro (Rigaku, V1.171.39.30d, 2017) software which corrects for Lorentz polarisation. The final completeness is $100.00 \%$ out to $27.484^{\circ}$ in $\Theta$.

A multi-scan absorption correction was performed using CrysAlisPro 1.171.39.30d (Rigaku Oxford Diffraction, 2017) Empirical absorption correction using spherical harmonics, implemented in SCALE3 ABSPACK scaling algorithm. The absorption coefficient $\mu$ of this material is $2.624 \mathrm{~mm}^{-1}$ at this wavelength $(\lambda=0.71075 \AA)$ and the minimum and maximum transmissions are 0.65235 and 1.00000 .

The structure was solved in the space group Aea2 (\# 41) by Intrinsic Phasing using the ShelXT (Sheldrick, 2015) structure solution program and refined by Least Squares using version 2014/7 of ShelXL (Sheldrick, 2015). All non-hydrogen atoms were refined anisotropically. Hydrogen atom positions were calculated geometrically and refined using the riding model.

There is a single molecule in the asymmetric unit, which is represented by the reported sum formula. In other words: $\mathrm{Z}$ is 8 and $\mathrm{Z}^{\prime}$ is 1.

The Flack parameter was refined to $0.007(16)$. Determination of absolute structure using Bayesian statistics on Bijvoet differences using the Olex2 results in 0.033(11). Note: The Flack parameter is used to determine chirality of the crystal studied, the value should be near 0 , a value of 1 means that the stereochemistry is wrong and the model should be inverted. A value of 0.5 means that the crystal consists of a racemic mixture of the two enantiomers. 


\section{Crystal Data and Experimental for $\left[\mathrm{Ce}\left(\mathrm{NO}_{3}\right)_{3}\left(\mathrm{Et}_{3} \mathrm{PO}\right)_{3}\right]\left[\mathrm{NO}_{3}\right]$}

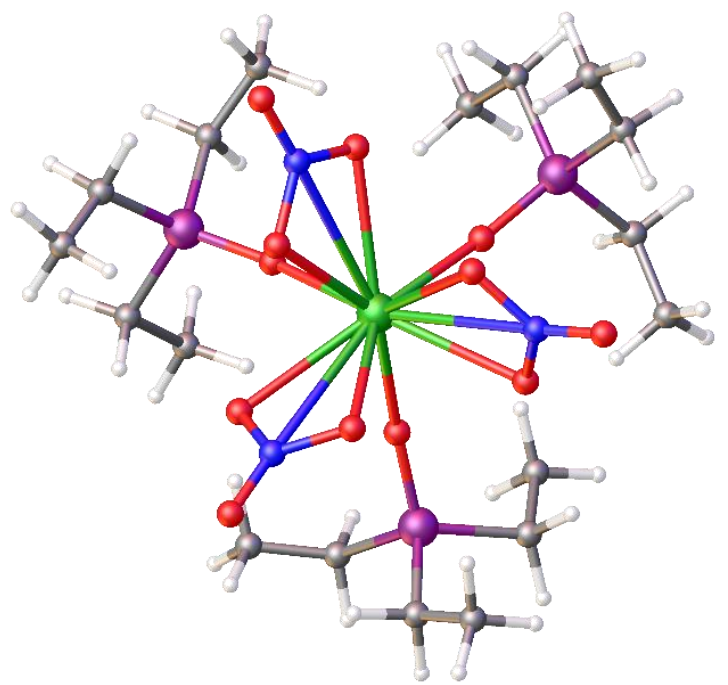

Figure 1: Thermal ellipsoids drawn at the $50 \%$ probability level

Experimental. A suitable light yellow block-shaped crystal of 2018ncs0267 $\left(0.300 \times 0.250 \times 0.150 \mathrm{~mm}^{3}\right)$ was selected and mounted on a MITIGEN holder in perfluoroether oil on a Rigaku FRE+ diffractometer equipped with VHF Varimax confocal mirrors and an AFC12 goniometer and HyPix 6000HE detector. The crystal was kept at a steady $T=100.00(10) \mathrm{K}$ during data collection. The structure was solved with the ShelXT (Sheldrick, 2015) structure solution program using the Intrinsic Phasing solution method and by using Olex2 (Dolomanov et al., 2009) as the graphical interface. The model was refined with version 2014/7 of ShelXL (Sheldrick, 2015) using Least Squares minimisation.

Crystal Data. $\mathrm{C}_{18} \mathrm{H}_{45} \mathrm{CeN}_{3} \mathrm{O}_{12} \mathrm{P}_{3}, M_{r}=728.60$, hexagonal, $P 6_{3}$ (No. 173), $a=16.2791(3) \AA, b=16.2791(3) \AA, c=$ 8.3776(2) $\AA, \alpha=90^{\circ}, \beta=90^{\circ}, \gamma=120^{\circ}, V=1922.69(9) \AA^{3}, T$ $=100.00(10) \mathrm{K}, Z=1.99998, Z^{\prime}=0.33333, \mu\left(\mathrm{MoK}_{\alpha}\right)=$ $1.354 \mathrm{~mm}^{-1}, 86383$ reflections measured, 2941 unique $\left(R_{\text {int }}=0.0639\right)$ which were used in all calculations. The final $w R_{2}$ was 0.1338 (all data) and $R_{1}$ was 0.0503 (I > 2(I)).

\begin{tabular}{|c|c|}
\hline Compound & 2018ncs0267 \\
\hline Formula & $\mathrm{C}_{18} \mathrm{H}_{45} \mathrm{CeN}_{3} \mathrm{O}_{12} \mathrm{P}_{3}$ \\
\hline$D_{\text {calc. }} / \mathrm{g} \mathrm{cm}^{-3}$ & 1.259 \\
\hline$\mu / \mathrm{mm}^{-1}$ & 1.354 \\
\hline Formula Weight & 728.60 \\
\hline Colour & light yellow \\
\hline Shape & block \\
\hline $\mathrm{Size} / \mathrm{mm}^{3}$ & $0.300 \times 0.250 \times 0.150$ \\
\hline$T / \mathrm{K}$ & $100.00(10)$ \\
\hline Crystal System & hexagonal \\
\hline Flack Parameter & $0.300(11)$ \\
\hline Hooft Parameter & $0.266(4)$ \\
\hline Space Group & $P 63$ \\
\hline$a / \AA$ & $16.2791(3)$ \\
\hline$b / \AA ̊$ & $16.2791(3)$ \\
\hline$c / \AA$ & $8.3776(2)$ \\
\hline$\left.\alpha\right|^{\circ}$ & 90 \\
\hline$\beta /^{\circ}$ & 90 \\
\hline$\left.\gamma\right|^{\circ}$ & 120 \\
\hline $\mathrm{V} / \AA^{3}$ & $1922.69(9)$ \\
\hline$Z$ & 1.99998 \\
\hline$Z^{\prime}$ & 0.33333 \\
\hline Wavelength/Å & 0.71075 \\
\hline Radiation type & $\operatorname{MoK}_{\alpha}$ \\
\hline$\Theta_{\min } /^{\circ}$ & 2.502 \\
\hline$\Theta_{\max } /{ }^{\circ}$ & 27.484 \\
\hline Measured Refl. & 86383 \\
\hline Independent Refl. & 2941 \\
\hline $\begin{array}{l}\text { Reflections with I > } \\
2(\mathrm{I})\end{array}$ & 2839 \\
\hline Rint & 0.0639 \\
\hline Parameters & 106 \\
\hline Restraints & 1 \\
\hline Largest Peak & 1.980 \\
\hline Deepest Hole & -0.430 \\
\hline GooF & 1.071 \\
\hline$w R_{2}$ (all data) & 0.1338 \\
\hline$w R_{2}$ & 0.1324 \\
\hline$R_{1}$ (all data) & 0.0518 \\
\hline$R_{1}$ & 0.0503 \\
\hline
\end{tabular}


Structure Quality Indicators

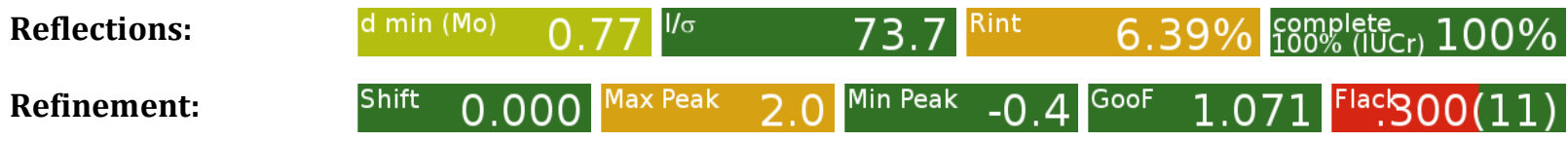

A light yellow block-shaped crystal with dimensions $0.300 \times 0.250 \times 0.150 \mathrm{~mm}^{3}$ was mounted on a MITIGEN holder in perfluoroether oil. Data were collected using a Rigaku FRE+ diffractometer equipped with VHF Varimax confocal mirrors and an AFC12 goniometer and HyPix 6000HE detector, and equipped with an Oxford Cryosystems low-temperature device operating at $T=100.00(10) \mathrm{K}$.

Data were measured using $\omega$ scans of $0.5^{\circ}$ per frame for $1 \mathrm{~s}$ using $\mathrm{MoK}_{\alpha}$ radiation. The total number of runs and images was based on the strategy calculation from the program CrysAlisPro (Rigaku, V1.171.39.46, 2018). The maximum resolution that was achieved was $\Theta=27.484^{\circ}(0.77 \AA)$.

Cell parameters were retrieved using the CrysAlisPro (Rigaku, V1.171.39.46, 2018) software and refined using CrysAlisPro (Rigaku, V1.171.39.46, 2018) on 27221 reflections, 32\% of the observed reflections.

Data reduction, scaling and absorption corrections were performed using CrysAlisPro (Rigaku, V1.171.39.46, 2018). The final completeness is $99.90 \%$ out to $27.484^{\circ}$ in $\Theta$.

A multi-scan absorption correction was performed using CrysAlisPro 1.171.39.46 (Rigaku Oxford Diffraction, 2018) using spherical harmonics as implemented in SCALE3 ABSPACK. The absorption coefficient $\mu$ of this material is $1.354 \mathrm{~mm}^{-1}$ at this wavelength $(\lambda=0.711 \AA)$ and the minimum and maximum transmissions are 0.530 and 1.000 .

The structure was solved and the space group $\mathrm{P6}_{3}$ (\# 173) determined by the ShelXT (Sheldrick, 2015) structure solution program using Intrinsic Phasing and refined by Least Squares using version 2014/7 of ShelXL (Sheldrick, 2015). All non-hydrogen and non-carbon atoms were refined anisotropically. The disordered carbon atoms were refined isotropically, together with the occupancy factors for part 1 and part 2. Hydrogen atom positions were calculated geometrically and refined using the riding model. The $\mathrm{CH} 3$ hydrogens were geometrically calculated (AFIX 33). There are voids (channels) in the structure of about 360 $\AA^{3}$. No obvious solvent molecules were found, so the structure was SQUEEZEd.

The value of $Z^{\prime}$ is 0.33333 .

The Flack parameter was refined to $0.300(11)$. Determination of absolute structure using Bayesian statistics on Bijvoet differences using the Olex2 results in 0.266(4). Note: The Flack parameter is used to determine chirality of the crystal studied, the value should be near 0 , a value of 1 means that the stereochemistry is wrong and the model should be inverted. A value of 0.5 means that the crystal consists of a racemic mixture of the two enantiomers.

The crystal has disordered Et groups, part 1 and part 2. The occupancy of the groups was refined as 0.53(1) and $0.47(1)$ respectively, so not significantly different from $0.5-0.5$. 


\section{Crystal Data and Experimental for $\mathrm{Ce}\left(\mathrm{NO}_{3}\right)_{3}\left(\mathrm{Cy}_{3} \mathrm{PO}\right)_{3}$}

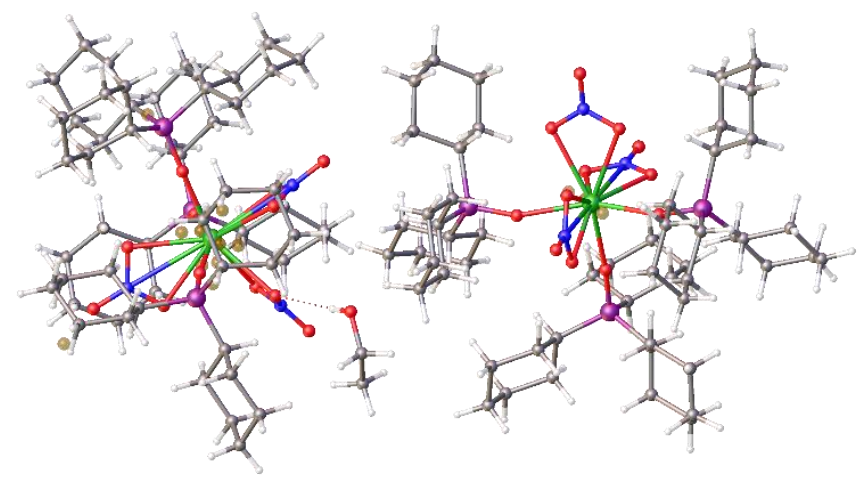

Figure 1: Thermal ellipsoids drawn at the $50 \%$ probability level.

Experimental. A suitable colourless block-shaped crystal of 2018ncs0521 $\left(0.400 \times 0.300 \times 0.100 \mathrm{~mm}^{3}\right)$ was selected and mounted on a MITIGEN holder in perfluoroether oil on an Rigaku FRE+ diffractometer equipped with VHF Varimax confocal mirrors and an AFC12 goniometer and HyPix 6000HE detector. The crystal was kept at a steady $T$ $=100.00(10) \mathrm{K}$ during data collection. The structure was solved with the ShelXT (Sheldrick, 2015) structure solution program using the Intrinsic Phasing solution method and by using 0lex2 (Dolomanov et al., 2009) as the graphical interface. The model was refined with version 2014/7 of ShelXL (Sheldrick, 2015) using Least Squares minimisation.

Crystal Data. $\mathrm{C}_{110} \mathrm{H}_{204} \mathrm{Ce}_{2} \mathrm{~N}_{6} \mathrm{O}_{25} \mathrm{P}_{6}, \quad M_{r}=2476.84$, monoclinic, $P 2_{1} \quad$ (No. 4), $a=11.71280(10) \AA, \quad b=$ $18.73370(10) \AA, \mathrm{c}=28.5137(2) \AA \AA, \beta=100.1860(10)^{\circ}, \alpha=$ $\gamma=90^{\circ}, V=6157.98(8) \AA^{3}, T=100(2) \mathrm{K}, Z=2, Z^{\prime}=1$, $\mu\left(\mathrm{MoK}_{\alpha}\right)=0.876 \mathrm{~mm}^{-1}, 282488$ reflections measured, 28239 unique $\left(R_{\text {int }}=0.0667\right)$ which were used in all calculations. The final $w R_{2}$ was 0.0777 (all data) and $R_{1}$ was $0.0306(\mathrm{I}>2(\mathrm{I}))$.

\begin{tabular}{|c|c|}
\hline Compound & 2018ncs0521 \\
\hline Formula & $\mathrm{C}_{110} \mathrm{H}_{204} \mathrm{Ce}_{2} \mathrm{~N}_{6} \mathrm{O}_{25} \mathrm{P}_{6}$ \\
\hline$D_{\text {calc. }} / \mathrm{g} \mathrm{cm}^{-3}$ & 1.336 \\
\hline$\mu / \mathrm{mm}^{-1}$ & 0.876 \\
\hline Formula Weight & 2476.84 \\
\hline Colour & colourless \\
\hline Shape & block \\
\hline $\mathrm{Size} / \mathrm{mm}^{3}$ & $0.400 \times 0.300 \times 0.100$ \\
\hline$T / \mathrm{K}$ & $100.00(10)$ \\
\hline Crystal System & monoclinic \\
\hline Flack Parameter & $-0.018(5)$ \\
\hline Hooft Parameter & $-0.0020(16)$ \\
\hline Space Group & $P 2_{1}$ \\
\hline$a / \AA$ & $11.71280(10)$ \\
\hline$b / \AA$ & $18.73370(10)$ \\
\hline$c / \AA$ & $28.5137(2)$ \\
\hline$\alpha /^{\circ}$ & 90 \\
\hline$\beta /^{\circ}$ & $100.1860(10)$ \\
\hline$\gamma /^{\circ}$ & 90 \\
\hline $\mathrm{V} / \AA^{3}$ & $6157.98(8)$ \\
\hline$Z$ & 2 \\
\hline$Z^{\prime}$ & 1 \\
\hline Wavelength/Å & 0.71075 \\
\hline Radiation type & $\mathrm{MoK}_{\alpha}$ \\
\hline$\Theta_{\min } /^{\circ}$ & 1.767 \\
\hline$\left.\Theta_{\max }\right|^{\circ}$ & 27.485 \\
\hline Measured Refl. & 282488 \\
\hline Independent Refl. & 28239 \\
\hline $\begin{array}{l}\text { Reflections with I > } \\
2(\mathrm{I})\end{array}$ & 27612 \\
\hline Rint & 0.0667 \\
\hline Parameters & 1344 \\
\hline Restraints & 1 \\
\hline Largest Peak & 1.079 \\
\hline Deepest Hole & -0.962 \\
\hline GooF & 1.051 \\
\hline$w R_{2}$ (all data) & 0.0777 \\
\hline$w R_{2}$ & 0.0773 \\
\hline$R_{1}$ (all data) & 0.0314 \\
\hline$R_{1}$ & 0.0306 \\
\hline
\end{tabular}




\section{Structure Quality Indicators}

\section{Reflections:

$\mathrm{d} \min (\mathrm{Mo}) \quad 0.77$ \\ $1 / \sigma \quad 35.5$ \\ Rint \\ $6.67 \%$ complete $100 \%$ \\ Refinement: \\ Shift -0.001

A colourless block-shaped crystal with dimensions $0.400 \times 0.300 \times 0.100 \mathrm{~mm}^{3}$ was mounted on a MITIGEN holder in perfluoroether oil. Data were collected using a Rigaku FRE+ diffractometer equipped with VHF Varimax confocal mirrors and an AFC12 goniometer and HyPix 6000HE detectore, and quipped with an Oxford Cryosystems low-temperature device operating at $T=100.00(10) \mathrm{K}$.

Data were measured using $\omega$ scans of $0.5^{\circ}$ per frame for $0.5 \mathrm{~s}$ using $\mathrm{MoK}_{\alpha}$ radiation (Rotating-anode $\mathrm{X}$-ray tube, $40 \mathrm{kV}, 30 \mathrm{~mA}$ ). The total number of runs and images was based on the strategy calculation from the program CrysAlisPro (Rigaku, V1.171.39.46, 2018). The maximum resolution that was achieved was $\Theta=27.485^{\circ}(0.77 \AA)$.

Cell parameters were retrieved using the CrysAlisPro (Rigaku, V1.171.39.46, 2018) software and refined using CrysAlisPro (Rigaku, V1.171.39.46, 2018) on 192437 reflections, 68\% of the observed reflections.

Data reduction, scaling and absorption corrections were performed using CrysAlisPro (Rigaku, V1.171.39.46, 2018). The final completeness is $100.00 \%$ out to $27.485^{\circ}$ in $\Theta$.

A multi-scan absorption correction was performed using CrysAlisPro 1.171.39.46 (Rigaku Oxford Diffraction, 2018) using spherical harmonics as implemented in SCALE3 ABSPACK. The absorption coefficient $\mu$ of this material is $0.876 \mathrm{~mm}^{-1}$ at this wavelength $(\lambda=0.71075 \AA)$ and the minimum and maximum transmissions are 0.402 and 1.000 .

The structure was solved and the space group $P 2_{1}$ (\# 4) determined by the ShelXT (Sheldrick, 2015) structure solution program using Intrinsic Phasing and refined by Least Squares using version 2014/7 of ShelXL (Sheldrick, 2015). All non-hydrogen atoms were refined anisotropically. Hydrogen atom positions were calculated geometrically and refined using the riding model.

There is a single molecule in the asymmetric unit, which is represented by the reported sum formula. In other words: $\mathrm{Z}$ is 2 and $\mathrm{Z}$ ' is 1 . However, there are actually 2 Ce molecules and 1 ethanol per asymmetric unit.

The Flack parameter was refined to -0.018(5). Determination of absolute structure using Bayesian statistics on Bijvoet differences using the Olex2 results in $-0.0020(16)$. Note: The Flack parameter is used to determine chirality of the crystal studied, the value should be near 0 , a value of 1 means that the stereochemistry is wrong and the model should be inverted. A value of 0.5 means that the crystal consists of a racemic mixture of the two enantiomers. 
Table S2 13-C data for $\mathrm{Ce}\left(\mathrm{NO}_{3}\right)_{4}\left(\mathrm{R}_{3} \mathrm{PO}\right)_{2}$ in $\mathrm{CDCl}_{3}$

\begin{tabular}{|c|c|c|c|c|}
\hline $\mathrm{Ce}\left(\mathrm{NO}_{3}\right)_{4}\left(\mathrm{R}_{3} \mathrm{PO}\right)_{2}$ & $\mathrm{CH}_{3}$ & $\mathrm{CH}_{2}$ & $\mathrm{CH}$ & $\mathrm{C}$ \\
\hline $\mathrm{Et}_{3} \mathrm{PO}$ & $4.95(\mathrm{~d}){ }^{2} \mathrm{~J}_{\mathrm{PC}} 5 \mathrm{~Hz}$ & $18.35^{1} \mathrm{~J}_{\mathrm{PC}} 65 \mathrm{~Hz}$ & & \\
\hline 'Pr & $17.85(\mathrm{~s})$ & & $27.31(\mathrm{~d}){ }^{1} \mathrm{~J}_{\mathrm{PC}} 61 \mathrm{~Hz}$ & \\
\hline${ }^{\mathrm{n}} \mathrm{Bu}$ & $13.48(\mathrm{~s})$ & $\begin{array}{l}25.8 \text { (d) }{ }^{1} J_{\mathrm{PC}} 63 \mathrm{~Hz} \\
24.0 \text { (d) }{ }^{2} \mathrm{~J}_{\mathrm{PC}} 15 \mathrm{~Hz} \\
23.0 \text { (s) }\end{array}$ & & \\
\hline $\mathrm{Bu}$ & 24.04(d) ${ }^{2} J_{P C} 9 \mathrm{~Hz}$ & 36.31 (d) ${ }^{1} \mathrm{~J}_{\mathrm{PC}} 61 \mathrm{~Hz}$ & $23.04(d){ }^{2} J_{P C} 8 \mathrm{~Hz}$ & \\
\hline tBu & $28.97(s)$ & & & $39.31(d)^{1} J_{P C} 63 \mathrm{~Hz}$ \\
\hline Cy & & $\begin{array}{l}26.78(d)^{2} \mathrm{JPC}_{\mathrm{PC}} 12 \mathrm{~Hz} \\
25.64 \text { (d) }{ }^{3} \mathrm{JPC}_{\mathrm{PC}} 3 \mathrm{~Hz} \\
25.73 \text { (s) }\end{array}$ & 35.39 (d) ${ }^{1} J_{P C} 58 \mathrm{~Hz}$ & \\
\hline Oct & $14.18(s)$ & $\begin{array}{l}26.07 \text { (d) }{ }^{1} J_{\mathrm{PC}} 63 \mathrm{~Hz} \\
31.09 \text { (d) } \mathrm{J}_{\mathrm{PC}} 17 \mathrm{~Hz} \\
21.02 \text { (d) }{ }^{3} \mathrm{JPC}_{\mathrm{PC}} 3 \mathrm{~Hz} \\
31.8 \text { (s) } \\
29.04 \text { (s) } \\
28.93 \text { (s) }\end{array}$ & & \\
\hline & & & & \\
\hline
\end{tabular}


Table S2 Selected bond lengths

$\mathrm{Ce}\left(\mathrm{NO}_{3}\right)_{4}\left(\mathrm{Cy}_{3} \mathrm{PO}\right)_{2}$

\begin{tabular}{lll}
\hline Atom & Atom & Length/Å \\
\hline Ce1 & $01^{1}$ & $2.239(3)$ \\
Ce1 & 01 & $2.240(3)$ \\
Ce1 & $03^{1}$ & $2.478(3)$ \\
Ce1 & 03 & $2.478(3)$ \\
Ce1 & $04^{1}$ & $2.506(4)$ \\
Ce1 & 04 & $2.506(4)$ \\
Ce1 & $06^{1}$ & $2.472(3)$ \\
Ce1 & 06 & $2.472(3)$ \\
Ce1 & O71 & $2.476(3)$
\end{tabular}

$\mathrm{Ce}\left(\mathrm{NO}_{3}\right)_{3}\left(\mathrm{H}_{2} \mathrm{O}\right)_{3}\left(\mathrm{Et}_{3} \mathrm{PO}\right)$

\begin{tabular}{|c|c|c|}
\hline Atom & Atom & Length/Å \\
\hline Ce1 & 02 & $2.656(13)$ \\
\hline Ce1 & 03 & $2.693(15)$ \\
\hline Ce1 & 05 & $2.625(15)$ \\
\hline Ce1 & 06 & $2.653(14)$ \\
\hline Ce1 & 08 & $2.614(14)$ \\
\hline Ce1 & 09 & $2.670(13)$ \\
\hline Ce1 & 010 & $2.515(15)$ \\
\hline Ce1 & 011 & $2.501(14)$ \\
\hline Ce1 & 012 & $2.519(15)$ \\
\hline Ce1 & 013 & $2.318(16)$ \\
\hline
\end{tabular}

${ }^{1} 1-x,+y, 1 / 2-z \quad 21+y-x, 1-x,+z ;{ }^{3} 1-y,+x-y,+z$
$\left[\mathrm{Ce}\left(\mathrm{NO}_{3}\right)_{3}\left(\mathrm{Cy}_{3} \mathrm{PO}\right)_{3}\right.$

\begin{tabular}{lll}
\hline Atom & Atom & Length/Å \\
\hline Ce1 & 01 & $2.368(3)$ \\
Ce1 & O2 & $2.400(2)$ \\
Ce1 & O3 & $2.382(2)$ \\
Ce1 & 04 & $2.597(3)$ \\
Ce1 & O6 & $2.603(3)$ \\
Ce1 & 07 & $2.565(3)$ \\
Ce1 & 09 & $2.603(3)$ \\
Ce1 & 010 & $2.634(3)$ \\
Ce1 & 012 & $2.619(3)$
\end{tabular}

$\left[\mathrm{Ce}\left(\mathrm{NO}_{3}\right)_{3}\left(\mathrm{Et}_{3} \mathrm{PO}\right)_{3}\right]\left[\mathrm{NO}_{3}\right] \mathrm{CHCl}_{3}$.

\begin{tabular}{|c|c|c|}
\hline Atom & Atom & Length/Å \\
\hline$\overline{\mathrm{Ce} 1}$ & $01^{2}$ & $2.455(7)$ \\
\hline Ce1 & $01^{3}$ & $2.455(7)$ \\
\hline $\mathrm{Ce} 1$ & 01 & $2.455(7)$ \\
\hline $\mathrm{Ce} 1$ & $02^{3}$ & $2.509(6)$ \\
\hline Ce1 & $\mathrm{O} 2^{2}$ & $2.509(6)$ \\
\hline Ce1 & 02 & $2.509(6)$ \\
\hline Ce1 & $04^{2}$ & $2.199(7)$ \\
\hline Ce1 & 04 & $2.199(7)$ \\
\hline Ce1 & $04^{3}$ & $2.199(7)$ \\
\hline
\end{tabular}

